\title{
LETTERS
}

\section{Erdheim-Chester disease in Brazil}

\section{D Lopes Marques, Â L Branco Pinto Duarte, F de Souza Cavalcanti}

Ann Rheum Dis 2003;62:270

$B$ reuil et al reported on a patient with Erdheim-Chester disease. ${ }^{1}$ We would like to add our experience in a patient who had a good response to steroids. A 46 year old housewife, born in Maceio (Brazil), complained of pain in her legs for a period of eight months, which interfered with her sleep; there were no constitutional symptoms, such as weight loss, asthenia, or fever. On physical examination, there was no systemic involvement or bone inflammation, except for tenderness on palpation of both tibiae. An $x$ ray examination showed bilateral and symmetrical cortical osteosclerosis of the diaphysial regions of the tibiae, which was better illustrated with magnetic resonance imaging (MRI) which showed a low signal on $\mathrm{T}_{1}$ and a high signal on $\mathrm{T}_{2}$ of the medullar canal (fig 1). Bone scintigraphy showed intense hypercapitation at the upper and medial regions of the right tibia and the medial region of the left tibia (fig 2). Other MR images (brain, thorax, and abdomen) were normal. A bone biopsy showed only osteosclerosis, which has been described in this disease. ${ }^{2}$

She was treated with steroids for six months (prednisone 20 $\mathrm{mg} /$ day) and responded well, being asymptomatic and receiv-

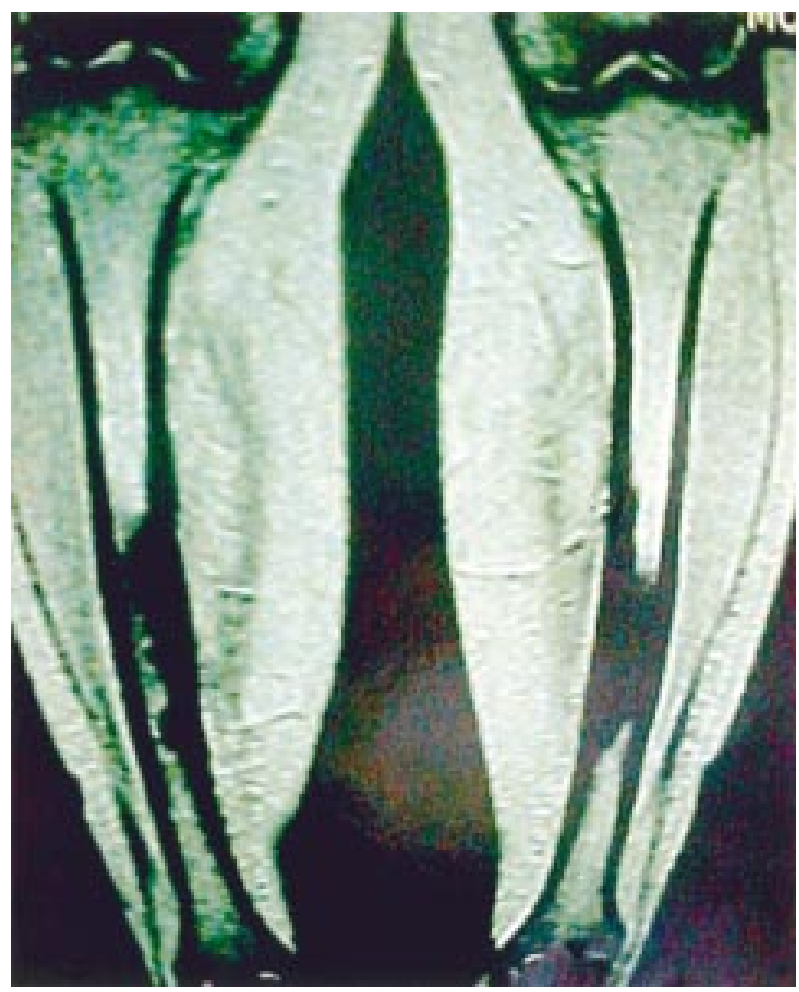

Figure 1 MRI showing a low signal on $T_{1}$ and high signal on $T_{2}$ of the medullar canal. ing no treatment since December 2000. As bone pain is the first symptom of this xanthogranulomatosis, rheumatologists should be able to recognise the disease in an early phase when treatment gives a better outcome.

\section{Authors' affiliations}

C D Lopes Marques, Â L Branco Pinto Duarte, F de Souza

Cavalcanti, Department of Rheumatology, Universidade Federal de Pernambuco, Rua Ast Neil Armstrong 43, 52060-170 Recife, Brazil

Correspondence to: Dr F de Souza Cavalcanti; cerepe@nlink.com.br Accepted 8 August 2002

\section{REFERENCES}

1 Breuil V, Brocq O, Pellegrino C, Grimaud AS, Euller-Ziegler L. Erdheim-Chester disease: typical radiological bone features for a rare xanthogranulomatosis. Ann Rheum Dis 2002;61:199-200.

2 Miller RL, Sheeler LR, Bauer TW, Bukowski RM. Erdheim-Chester disease. Case report and review of the literature. Am J Med 1986;80:1230-6.

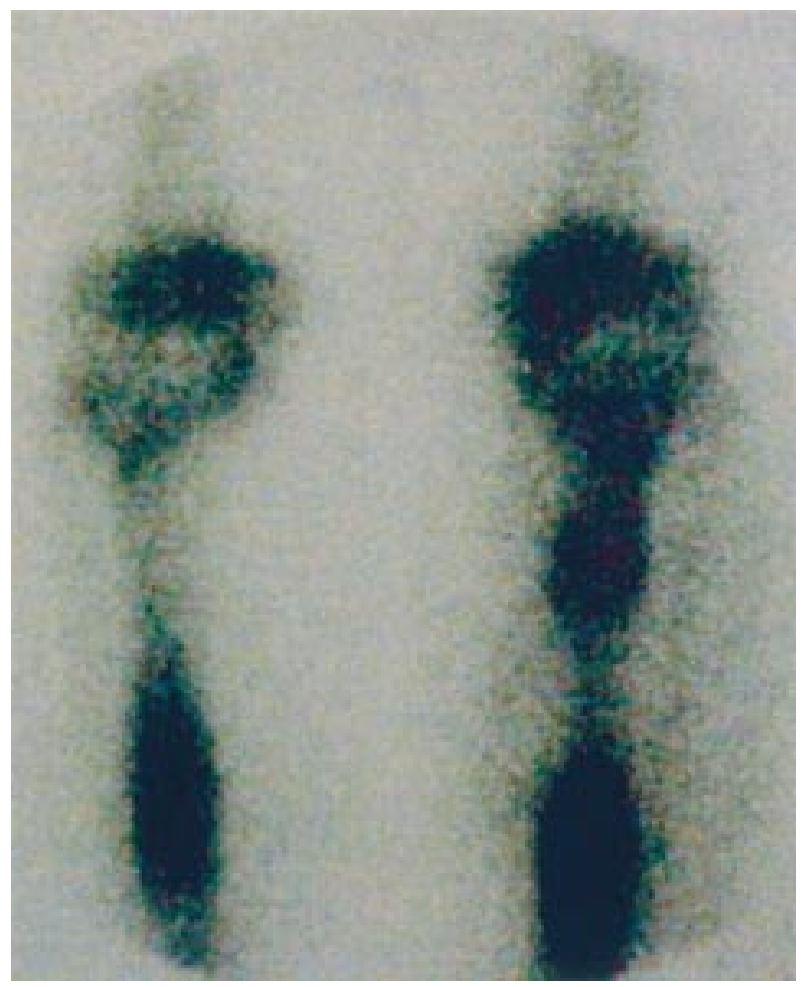

Figure 2 Bone scintigraphy with intense hypercapitation of the tibias. 


\title{
Erdheim-Chester disease with early onset atherosclerosis and a pseudo-malignant phase
}

\author{
R L Neame, G R Struthers
}

Ann Rheum Dis 2003;62:271-272

W read with interest the article by Breuil et al discussing Erdheim-Chester disease. ${ }^{1}$ We report on another man with this rare form of histiocytosis, who showed the unusual features of premature atherosclerosis and a pseudo-malignant phase.

\section{CASE REPORT}

A 42 year old man presented to the rheumatology department with a two year history of arthralgia of the knees and ankles. Past medical history included myocardial infarctions at the ages of 33 and 40, with coronary artery bypass grafting at age 39. His father had died of myocardial infarction aged 54. The patient was noted to have xanthomata. Examination of his joints was normal. Laboratory tests, including erythrocyte sedimentation rate, red and white blood cell count, glucose, renal, and liver function tests, were normal. Serum cholesterol was raised at $7.8 \mathrm{mmol} / \mathrm{l}$. Radiographs showed no abnormality of the joints, but demonstrated sclerosis of the distal femora and proximal tibia. Computed tomography (fig 1) and magnetic resonance imaging confirmed sclerosis without osteolysis. Biopsy of the left tibia showed sheets of large foamy histiocytes infiltrating the marrow, confirming the diagnosis of Erdheim-Chester disease. One year later, over a few weeks, he developed a painful swelling in the right mid-thigh associated with low grade fever and weight loss. Repeat blood cultures were negative and no material was aspirated. Radiographs showed a more aggressive appearance with erosion of the cortex, and possible malignant change. A second bone biopsy was performed under general anaesthetic. In the early postoperative period he died of bronchopneumonia and respiratory failure.

At post mortem longitudinal sections of the right femur showed a yellow haemorrhagic infiltrate filling the medullary cavity and eroding the cortex. Histological changes were thickened trabeculae and marrow spaces filled with a mixed inflammatory infiltrate, in which there were numerous lipid laden macrophages. There was erosion of the cortex and the infiltrate extended into the adjacent soft tissues. An oil red O stain for lipid was positive, and there was no malignant change. There were foamy macrophages within the lungs and within the enlarged neck lymph nodes.

\section{DISCUSSION}

Since the first cases of Erdheim-Chester disease were reported in $1930,{ }^{2}$ an increasing clinical spectrum has emerged. ${ }^{3}$ However, to our knowledge this patient is the first with lymph node involvement. The pseudo-malignant phase has not previously been reported, although a discharging sinus in the thigh has been observed. ${ }^{4}$ Premature atherosclerosis was the third unusual feature, and lipid laden histiocytes characterise this disease. ${ }^{5}$ The family history suggests that this patient had coincidental familial hypercholesterolaemia, although raised fasting lipids have been found previously in patients with this disease, ${ }^{36}$ and there is a report of premature death from renal and cardiovascular failure. ${ }^{7}$ There is no established treatment for this rare disease, and death from respiratory failure, as in this case, is a recognised outcome. ${ }^{8}$

\section{Authors' affiliations}

R L Neame, Department of Academic Rheumatology, Clinical Sciences Building, City Hospital, Nottingham NG5 1PB, UK

G R Struthers, Department of Rheumatology, University Hospitals

Coventry and Warwickshire NHS Trust, Walsgrave Hospital, Clifford

Bridge Road, Coventry CV2 2DX, UK

Correspondence to: Dr R L Neame; Rebecca.Neame@nottingham.ac.uk

Accepted 24 June 2002

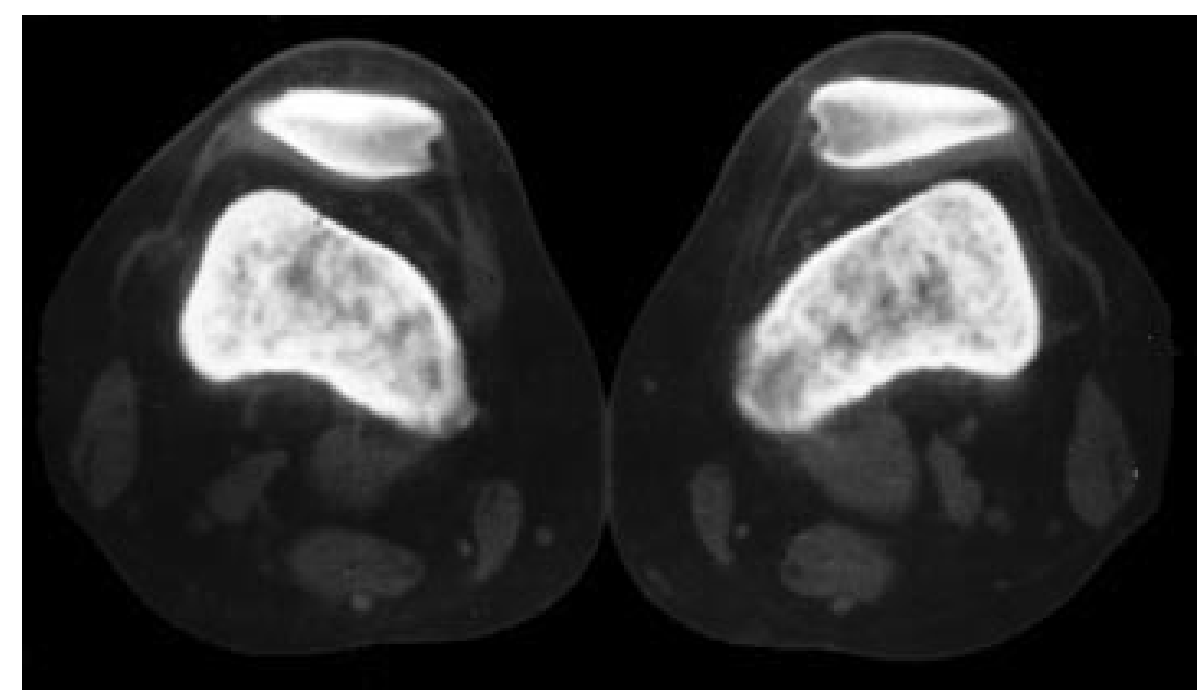

Figure 1 Computed tomography scan showing bilateral osteosclerosis of the femora. 


\section{REFERENCES}

1 Breuil V, Brocq O, Pellegrino C, Grimaud A, Euller-Ziegler L. Erdheim-Chester disease: typical radiological bone features for a rare xanthogranulomatosis. Ann Rheum Dis 2002;61:99-200.

2 Chester W. Uber lipoidgranulomatose. Virchows Arch Pathol Anat 1930;279:561-602

3 Kenn W, Stabler A, Zachoval R, Zietz C, Raum W, Wittenberg G. Erdheim-Chester disease: a case report and literature review. Eur Radiol 1999:9: 153-8.

4 Dee P, Westgaard T, Langholm R. Erdheim-Chester disease: case with chronic discharging sinus from bone. AJR Am J Roentgenol 1980; 134:837-9
5 Jaffe HL. Gauchers disease and certain other inborn metabolic disorders: Lipid (cholesterol) granulomatosis. In: Metabolic, degenerative and inflammatory disease of bone and joints. Philadelphia: Lea and Febiger, 1972:535-41.

6 Bancroft LW, Berquist TH. Erdheim-Chester disease: radiographic findings in five patients. Skeletal Radiol 1998;27:127-32.

7 Shields JA, Karcioglu ZA, Shields CL, Eagle RC, Wong S. Orbital and eyelid involvement with Erdheim-Chester disease. A report of two cases. Arch Ophthalmol 1991;109:850-4.

8 Rush WL, Andriko JAW, Galateau-Salle F, Brambilla E, Brambilla C, Ziany-bey I, et al. Pulmonary pathology of Erdheim-Chester disease. Mod Pathol 2000; 13:747-54.

\title{
Antinucleosome antibodies in the diagnosis of systemic lupus erythematosus
}

\author{
A P Cairns, S A McMillan, A D Crockard, G K Meenagh, E M Duffy, D J Armstrong, \\ A L Bell
}

$\mathrm{N}$ ucleosomes are fundamental units of chromatin released by internucleosomal cleavage during cell apoptosis, and nucleosomal material has been demonstrated in the surface blebs of apoptotic cells. ${ }^{1}$ Recent studies have shown the presence of antinucleosome antibodies in systemic lupus erythematosus (SLE). ${ }^{23}$ We measured the concentration of antinucleosome antibody present in the sera of patients with SLE and compared it with the concentration in healthy and disease control patients using a commercially available enzyme linked immunosorbent assay (ELISA) kit.

Peripheral blood was sampled from 95 white patients with SLE ( 87 female, median age 47.0 years), 48 white patients with rheumatoid arthritis (RA) (41 female, median age 55.5 years), 28 white patients with fibromyalgia (23 female, median age 47.0 years), and 95 white normal healthy volunteers (64 female, median age 31.0 years). All patients with SLE fulfilled the American College of Rheumatology (ACR) diagnostic criteria.

An indirect solid phase immunometric assay (ELISA) was used for the quantitative determination of IgG autoantibodies to nucleosomes (Organtec Diagnostika, Mainz, Germany; antinucleosome kit), according to the manufacturer's instructions. This assay is based on microplates coated with polynucleosomes, purified from a human cell line. The sensitivity

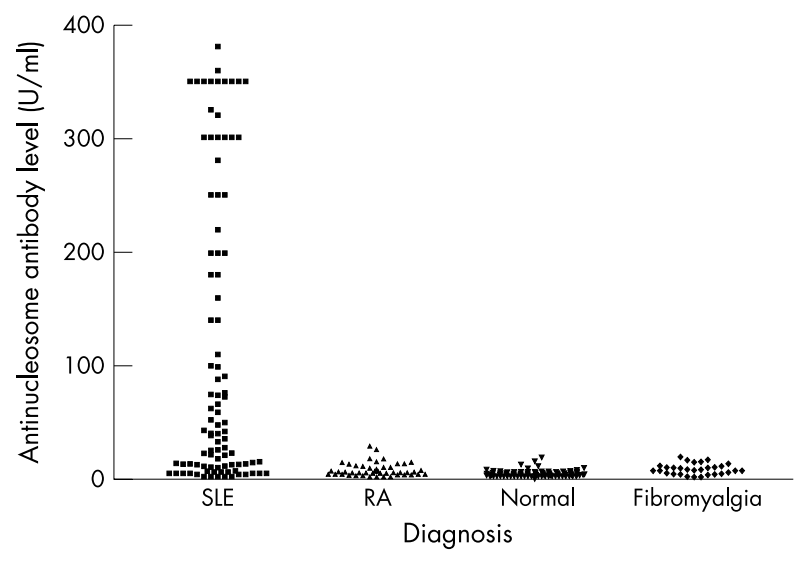

Figure 1 Scatter plot demonstrating the concentration of antinucleosome antibodies detected in each group of patients. Values $>20 \mathrm{U} / \mathrm{ml}$ are positive. of the test is given as $1 \mathrm{U} / \mathrm{ml}$. Values greater than $20 \mathrm{U} / \mathrm{ml}$ were recorded as positive, according to the manufacturer's instructions. dsDNA antibody concentrations were determined by the Farr assay (Immunodiagnostic Systems Ltd, Bolton, England; gamma-B anti-dsDNA kit). Values of $8 \mathrm{mg} / \mathrm{l}$ or above were recorded as positive. Non-parametric statistical methods were used.

The total number of patients with SLE $(n=95)$ fulfilling each ACR criterion was as follows: malar rash 53, discoid rash 9, photosensitivity 70 , oral ulcers 56 , arthritis 49 , serositis 17 , renal disorder 20, neurological disorder 11 , haematological disorder 63, immunological disorder 70, antinuclear antibody 91. Median SLE Activity Measure (SLAM) score was 6.0 (interquartile range 5.0-9.0). Serum antinucleosome antibody was positive $(>20 \mathrm{U} / \mathrm{ml})$ in $61 / 95(64 \%)$ patients with SLE, none of the healthy controls, none of the patients with fibromyalgia, and in 2/48 (4\%) rheumatoid arthritis controls (fig 1). Antinucleosome antibody concentrations were significantly higher in SLE (median $43.0 \mathrm{U} / \mathrm{ml}$ ) than in healthy controls (median $4.0 \mathrm{U} / \mathrm{ml}, \mathrm{p}<0.001$ ), fibromyalgia controls (median $8.3 \mathrm{U} / \mathrm{ml}, \mathrm{p}<0.001$ ) and rheumatoid arthritis controls (median $5.0 \mathrm{U} / \mathrm{ml}, \mathrm{p}<0.001$ ). Serum anti-dsDNA antibody levels were positive $(8 \mathrm{mg} / \mathrm{l})$ in $49 / 95(52 \%)$ patients with SLE, $3 / 48(6 \%)$ rheumatoid arthritis patients, none of the patients with fibromyalgia, and none of the healthy controls.

The antinucleosome antibody test therefore had a sensitivity of $64.2 \%$ compared with a sensitivity of $51.6 \%$ for the antidsDNA antibody test. The specificity of the antinucleosome antibody test $(98.8 \%)$ was similar to the specificity of the antidsDNA antibody test (98.2\%). Forty one (43\%) patients with SLE tested positive for both antinucleosome antibodies and anti-dsDNA antibodies. Twenty (21\%) patients with SLE were positive for only antinucleosome antibodies. Eight (8\%) patients with SLE were positive for only anti-dsDNA antibodies, and $26(27 \%)$ patients with SLE were negative for both anti-dsDNA and antinucleosome antibodies (table 1).

Antinucleosome antibody concentrations correlated positively with anti-dsDNA antibody titres $(r=0.493, \mathrm{p}<0.001)$. Antinucleosome antibody concentrations did not correlate significantly with the global SLAM score, or with the erythrocyte sedimentation rate. Antinucleosome antibody concentrations were higher in patients with SLE fulfilling renal criteria for diagnosis $(n=20$, median $80.5 \mathrm{U} / \mathrm{ml})$ than those not $(\mathrm{n}=75$, median $33.0 \mathrm{U} / \mathrm{ml}, \mathrm{p}=0.012)$, higher in patients with SLE fulfilling haematological criteria for diagnosis $(n=63$, 
Table 1 Numbers (percentage) of patients with SLE with anti-dsDNA antibodies and antinucleosome antibodies $(n=95)$

\begin{tabular}{lcl}
\hline & \multicolumn{2}{c}{ Anti-dsDNA } \\
\cline { 2 - 3 } & Positive & Negative \\
\hline $\begin{array}{l}\text { Antinucleosome } \\
\text { Positive }\end{array}$ & $41(43)$ & $20(21)$ \\
Negative & $8(8)$ & $26(27)$ \\
\hline
\end{tabular}

median $72.0 \mathrm{U} / \mathrm{ml})$ than those not $(\mathrm{n}=32$, median 14.5, $\mathrm{p}=0.003$ ), and higher in patients with SLE fulfilling immunological criteria for diagnosis $(n=70$, median $64.0 \mathrm{U} / \mathrm{ml})$ than those not $(\mathrm{n}=25$, median $14.0 \mathrm{U} / \mathrm{ml}, \mathrm{p}=0.027)$. In SLE the antinucleosome antibody concentration also correlated negatively with the lymphocyte count alone $(r=-0.379, \mathrm{p}<0.001)$, but not with total white cell count, neutrophil count, or monocyte count.

Our study confirms that antinucleosome antibodies are common in SLE. ${ }^{23}$ We have also shown that antinucleosome antibodies are not usually present in healthy subjects or in patients with rheumatoid arthritis or fibromyalgia. Our patients with SLE had relatively low disease activity, suggesting that antinucleosome antibodies are not confined to patients with active disease. The relationship of antinucleosome antibodies with lymphopenia has not previously been described. It could be speculated that apoptotic lymphocytes are a major source of nucleosomes for the development of autoantibodies. Alternatively, antinucleosome antibodies may cause lymphocyte apoptosis.

No single test exists for the diagnosis of SLE. The antinucleosome antibody ELISA that was used in this study is a straightforward laboratory test that can be performed on large numbers of samples in a relatively short period of time. More than one in five patients with SLE had antinucleosome antibodies but were negative for dsDNA antibodies. Thus the antinucleosome antibody test may be particularly useful in the diagnosis of SLE when anti-dsDNA antibodies are not present. A similar finding has recently been reported in a group of Korean patients with SLE. ${ }^{4}$ We therefore propose that an antinucleosome antibody ELISA test should be carried out (alongside other tests) to aid in the diagnosis of SLE.

\section{Authors' affiliations}

A P Cairns, G K Meenagh, D J Armstrong, A L Bell, Queen's University Musculoskeletal Education and Research Unit, Department of Rheumatology, Musgrave Park Hospital, Belfast, Northern Ireland, UK

E M Duffy, University of Ulster School of Biomedical Sciences, Coleraine, S A McMillan, A D Crockard, Regional Immunology Service, Royal

Victoria Hospital, Belfast, Northern Ireland, UK

Correspondence to: Dr A P Cairns, Department of Rheumatology, Musgrave Park Hospital, Stockman's Lane, Belfast BT9 7JB, Northern Ireland, UK; andrewcairns@doctors.org.uk

Accepted 3 July 2002

\section{REFERENCES}

1 Casciola-Rosen LA, Anhalt G, Rosen A. Autoantigens targeted in systemic lupus erythematosus are clustered in two populations of surface structures on apoptotic keratinocytes. J Exp Med 1994;179:1317-30.

2 Amoura Z, Koutouzov S, Chabre H, Cacoub P, Amoura I, Musset L, et al. Presence of antinucleosome autoantibodies in a restricted set of connective tissue diseases: antinucleosome antibodies of the $\lg G 3$ subclass are markers of renal pathogenicity in systemic lupus erythematosus. Arthritis Rheum 2000;43:76-84.

3 Bruns A, Blass S, Hausdorf G, Burmester GR, Hiepe F. Nucleosomes are major $T$ and $B$ cell autoantigens in systemic lupus erythematosus. Arthritis Rheum 2000;43:2307-15

4 Min DJ, Kim SJ, Park SH, Seo YI, Kang HJ, Kim WU, et al. Anti-nucleosome antibody: significance in lupus patients lacking anti-double-stranded DNA antibody. Clin Exp Rheumatol 2002;20:13-18.

\section{Bilateral distal fibular and tibial stress fractures associated with heavy smoking}

\section{S Mpofu, R J Moots, R N Thompson}

An unusual case of simultaneous bilateral stress fractures of the distal tibia and fibula in a 45 year old white woman is described. The onset of symptoms was not associated with a specific episode of trauma, sporting activity, or identifiable inflammatory predisposing cause. Her bone density scan, bone profile, and biochemistry were all normal. Although stress fractures are well recognised, bilateral distal tibial and fibular fractures are particularly rare. A high degree of awareness is required for early diagnosis.

\section{CASE HISTORY}

A 45 year old white housewife presented to the rheumatology outpatient clinic with a three month history of bilateral ankle swelling with pain. This was treated with a diuretic, which reduced the swelling but not the pain. She had a little difficulty in climbing stairs, and her walking distance was reduced to 200 metres from her normal distance of $2 \mathrm{~km}$. She took no alcohol and had a smoking history of 25 pack-years. She had a past history of hypothyroidism, had had a hysterectomy at the age of 35 for menorrhagia, and was receiving thyroxine and hormone replacement therapy. There was no past medical history of fracture or family history of metabolic or genetic bone diseases.

On examination she looked generally well, had a normal physical build, and was clinically euthyroid. Her weight was 80 $\mathrm{kg}$ and her body mass index $25 \mathrm{~kg} / \mathrm{m}^{2}$. She was normotensive and there were no abnormalities on systemic examination. She had pain on inversion and eversion of the subtalar joints bilaterally and her ankles were tender on palpation. She had bilateral valgus deformity at the ankle joint. There were no other joint abnormalities.

An $x$ ray examination of her ankles showed bilateral distal tibia and fibula stress fractures (fig l), and a bone isotope scan 

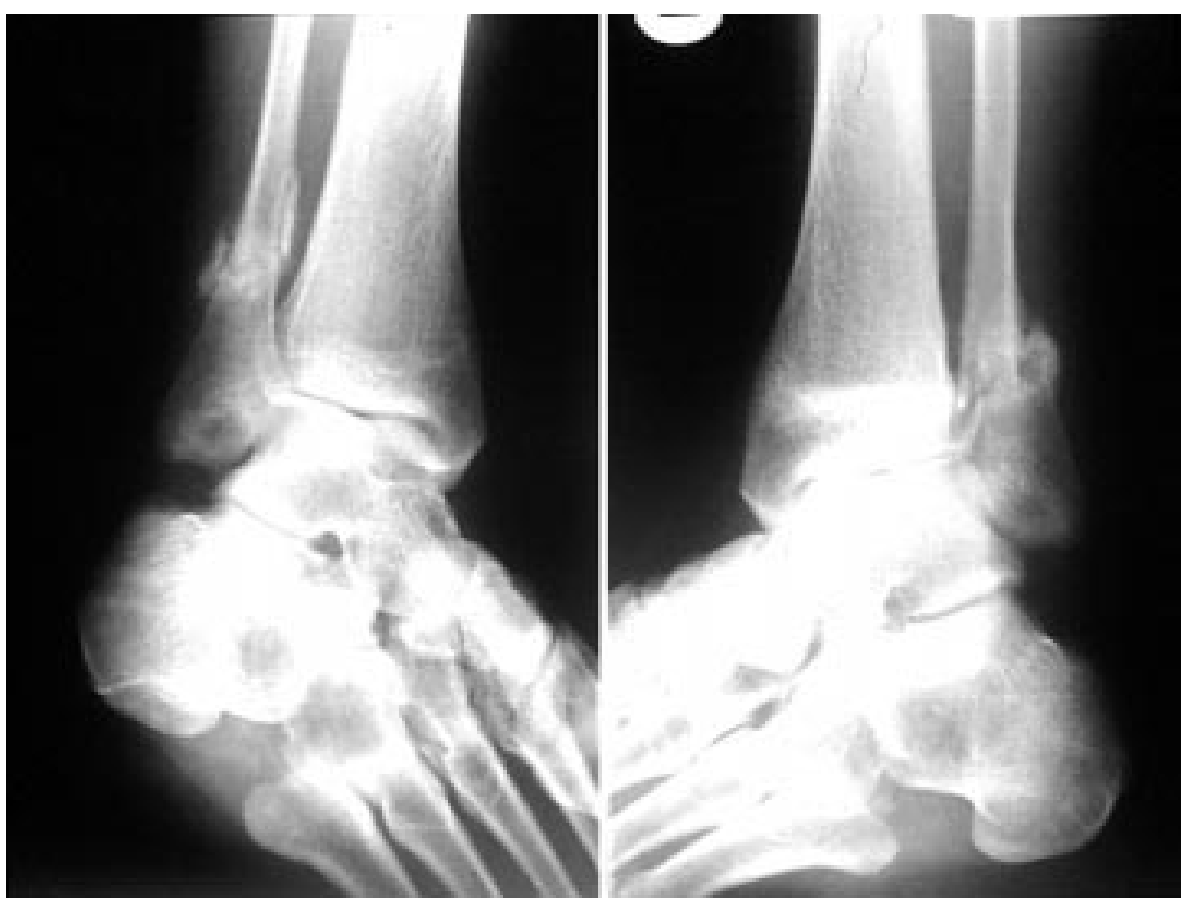

Figure 1 Healing distal fibular and tibial stress fractures.

confirmed increased distribution of the stress fractures. Serum 25-hydroxyvitamin D, parathyroid hormone, thyroxine, thyroid stimulating hormone, urinary creatinine/ dipyridinoline ratio, bone-specific sialoprotein, acute phase response proteins, serum protein electrophoresis, follicle stimulating hormone, luteinising hormone, and bone, liver, and kidney profiles were all normal. Bone density measurements were normal. Surgery was not recommended and she was advised to reduce her activity and rest and to use mechanical supports and analgesics; this resulted in successful symptomatic improvement. She was also advised to stop smoking.

\section{DISCUSSION}

Stress fractures can occur in almost any bone in the body, with the lower extremity weightbearing bones, especially the tibia, tarsals, and metatarsals, being most commonly affected. ${ }^{1-3}$ Stress fractures are common overuse injuries that are often seen in athletes and military recruits. In a study of 320 athletes the most common bones injured were the tibia $(49.1 \%)$ and the fibula $(6.6 \%)$, with stress fractures bilateral in $16.6 \%$ of cases. ${ }^{4}$ Isolated reports have indicated the development of these fractures in patients with specific clinical conditions such as rheumatoid arthritis, systemic lupus erythematosus, and calcium pyrophosphate deposition. ${ }^{5-9}$ Stress fractures occur when normal or physiological muscular activity stresses a bone that is deficient in mineral or elastic resistance. ${ }^{10}$ The exact mechanical phenomenon responsible for initiating stress fractures remains unclear. One theory suggests that excessive forces are transmitted to bone when surrounding muscles become fatigued. ${ }^{11}$ Other factors, genetic, nutritional deficiencies, metabolic bone disorders, and hormonal imbalances, known to contribute to stress fractures were not present in our patient. The valgus deformity at the ankles, ${ }^{5}$ heavy smoking, and surgically induced amenorrhoea, might have been predisposing factors. ${ }^{12} 13$

This case shows that pain and swelling localised to the ankles, associated with poor mobility, should alert doctors to the possibility of stress fractures in a patient with a history of heavy smoking, and amenorrhoea. Early recognition and diagnosis of stress fractures is important in helping to ameliorate the pain and disability they cause.

Authors' affiliations

S Mpofu, R J Moots, R N Thompson, University Hospital Aintree, Academic Rheumatology Unit, Liverpool, L9 7AL, UK

Correspondence: Dr S Mpofu; smpofu@liv.ac.uk

Accepted 14 August 2002

\section{REFERENCES}

1 Alonso-Bartolome P, Martinez-Taboada VM, Blanco R, Rodriguez-Valverde V. Insufficiency fractures of the tibia and fibula. Semin Arthritis Rheum 1999;28:413-20.

2 Boden BP, Osbahr DC, Jimenez C. Low-risk stress fractures. Am J Sports Med 2001;29:100-11.

3 Carpintero P, Berral FJ, Baena P, Garcia-Frasquet A, Lancho JL. Delayed diagnosis of fatigue fractures in the elderly. Am J Sports Med 1997;25:659-62

4 Matheson GO, Clement DB, McKenzie DC, Taunton JE, Lloyd-Smith DR Maclntyre JG. Stress fractures in athletes. A study of 320 cases. Am J Sports Med 1987; 15:46-58.

5 Pease CT. Insufficiency fractures of the distal tibia. Br J Rheumatol 1994;33:1056-9.

6 Maenpaa HM, Soini I, Lehto MU, Belt EA. Insufficiency fractures in patients with chronic inflammatory joint diseases. Clin Exp Rheumatol 2002;20:77-9

7 Wei N. Stress fractures of the distal fibula presenting as monoarticular flares in patients with rheumatoid arthritis. Arthritis Rheum 1994:37:1555-6.

8 Buskila D, Gladman DD. Stress fractures of the legs and swelling of the ankles in a patient with lupus: a diagnostic dilemma. Ann Rheum Dis 1990;49:783-4.

9 Ross DJ, Dieppe PA, Watt I, Newman JH. Tibial stress fracture in pyrophosphate arthropathy. J Bone Joint Surg Br 1983;65:474-7.

10 Stanitski CL, McMaster JH, Scranton PE: on the nature of stress fractures. Am J Sports Med 1978;6:391-6.

11 Meyer SA, Saltzman CL, Albright JP. Stress fractures of the foot and leg. Clin Sports Med 1993;12:395-413.

12 FriedI KE, Nuovo JA, Patience TH, Dettori JR. Factors associated with stress fracture in young army women: indications for further research. Mil Med 1992;157:334-8.

13 Lappe JM, Stegman MR, Recker RR. The impact of lifestyle factors on stress fractures in female Army recruits. Osteoporos Int 2001;12:35-42. 


\section{Zoledronate treatment in active Paget's disease}

\section{G Chung, R W Keen}

Ann Rheum Dis 2003;62:275-276

B isphosphonates are analogues of pyrophosphate that suppress bone remodelling through inhibition of osteoclast mediated bone resorption and are widely used in the management of various metabolic bone conditions: osteoporosis, Paget's disease, and hypercalcaemia of malignancy. Lately there has been increasing interest in the new third generation bisphosphonate, zoledronate, which is currently the most potent of its class available (10 000 times more potent than etidronate and 100 times more than pamidronate $\left.{ }^{1}\right)$. Zoledronate appears to be better than pamidronate in the treatment of cancer related hypercalcaemia, ${ }^{2}$ and a recent study in postmenopausal women with low bone mineral density (BMD) demonstrated improvements in BMD and suppression of bone turnover lasting for up to one year after a single $4 \mathrm{mg}$ infusion. ${ }^{3}$ We now wish to report a case of the use of zoledronate in active Paget's disease.

\section{CASE REPORT}

A 64 year old West Indian man with a 14 year history of polyostotic Paget's disease ( sites affected: skull, mandible, thoracolumbar spine, sacrum, pelvis, and left femur) was being regularly reviewed in the metabolic bone clinic. He had previously been treated at various times with injectable calcitonin (for six months), etidronate (for six months), tiludronate (for three months) and pamidronate (three courses: total doses 120, 60, and $240 \mathrm{mg}$ ), achieving variable symptomatic and biochemical responses. Recently his disease progressed and despite two further courses of intravenous pamidronate (total doses $120 \mathrm{mg}$ and $180 \mathrm{mg}$ ) there was no major reduction of serum alkaline phosphatase (fig 1). Biochemical activity continued to rise and he began to complain of facial pain. On clinical examination there was no neurological deficit. He was given a single infusion of intravenous zoledronate $4 \mathrm{mg}$. There were no acute reactions or complications and calcium levels and renal function after infusion remained normal. His symptoms improved over eight weeks and over a period of six months the alkaline phosphatase normalised, falling from 569 to $85 \mathrm{U} / \mathrm{l}$ (normal 30-130) (fig 1).

\section{DISCUSSION}

Paget's disease is the second commonest metabolic bone disease in the UK, affecting $2 \%$ of the population above the age of 55 years. ${ }^{4}$ The condition is characterised by focal increases in bone remodelling that can affect one or multiple sites. Active disease with symptoms indicates need for treatment, although patients with lesions at problematic sites (weightbearing bones, skull, spine, or bones around joints) should also be considered for antiresorptive treatment in the absence of symptoms, to prevent future complications. ${ }^{5}$ Bisphosphonates are regarded as the preferred treatment and short term studies have shown that they improve bone pain and biochemical markers of bone turnover in Paget's disease. Secondary resistance to bisphosphonates, after repeated courses of treatment, has been seen with etidronate ${ }^{6}$ and, more recently, with pamidronate. ${ }^{7}$ This acquired resistance to one bisphosphonate, demonstrated by a blunted alkaline phosphatase response or shorter remission duration, can usually be overcome by using a different bisphosphonate. ${ }^{7}$

With a single infusion of zoledronate we were able to achieve clinical and biochemical remission in our patient with active Paget's disease who had become resistant to pamidronate. Previous dose ranging studies, one of which was placebo controlled, have shown that single infusions of microgram amounts of zoledronate (up to $400 \mu \mathrm{g}$ ) inhibit bone resorption in patients with active Paget's disease ${ }^{89}$ and, in addition, no detectable impairment of bone mineralisation has been found..$^{10}$ The results of further studies examining the use of

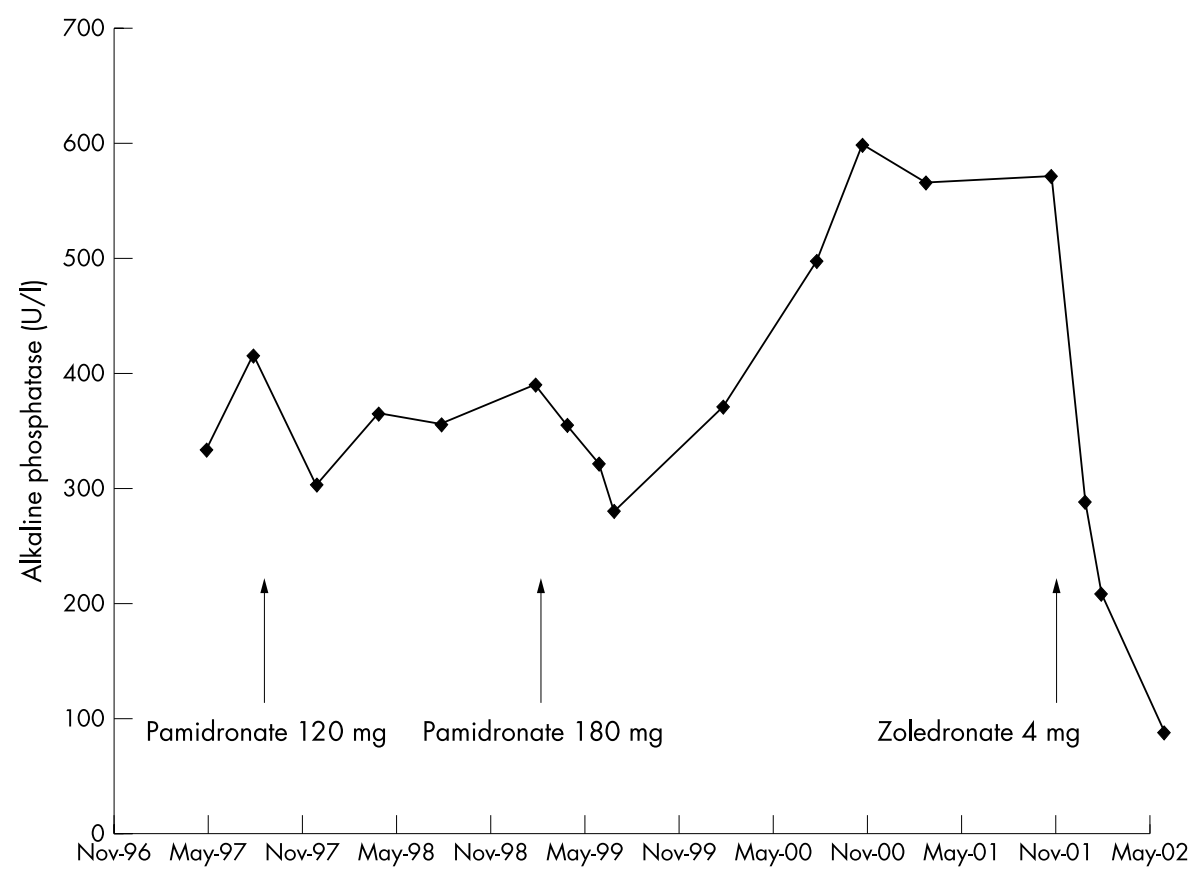

Figure 1 Serum alkaline phosphatase levels over a period of five years. Normal range 30-130 $\mathrm{U} / \mathrm{I}$. Timing of bisphosphonate treatment shown by arrows. 
zoledronate in patients with metabolic bone disease are awaited with interest.

\section{Authors' affiliations}

G Chung, R W Keen, Metabolic Unit, Royal National Orthopaedic

Hospital, Brockley Hill, Stanmore, Middlesex HA7 4LP, UK

R W Keen, Bone and Mineral Centre, Department of Medicine,

University College London, London WC1E 6JJ, UK

Correspondence to: Dr G Chung; gchungaziz@aol.com

Accepted 8 July 2002

\section{REFERENCES}

1 Fleisch H. Bisphosphonates in bone disease from the laboratory to the patient. 2nd ed. London: Parthenon, 1995.

2 Major PP, Coleman RE. Zoledronic acid in the treatment of hypercalcemia of malignancy: results of the international clinical development program. Semin Oncol 2001;28(suppl 6):17-24.

3 Reid IR, Brown JP, Burchardt P, Horowitz Z, Richardson P, Trechsel U, et al. Intravenous zoledronic acid in postmenopausal women with low bone mineral density. N Engl J Med 2002;346:653-61.
4 Cooper C, Schafheutle K, Dennison E, Kellingray S, Guyer P, Barker D. The epidemiology of Paget's disease in Britain: is the prevalence decreasing? J Bone Miner Res 1999; 14:192-7.

5 Graver A, Bone H, McCloskey EV, McClung M, Gutteridge DH, Lyles $\mathrm{KW}$, et al. Newer bisphosphonates in the treatment of Paget's disease of bone: where we are and where we want to go. J Bone Miner Res 1999; 14(suppl 2):74-8.

6 Altman RD. Long term follow up of therapy with intermittent etidronate disodium in Paget's disease of bone. Am J Med 1985;79:583-90.

7 Gutteridge DH, Ward LC, Stewart GO, Retallack RW, Will RK, Prince $\mathrm{RL}$, et al. Paget's disease: acquired resistance to one aminobisphosphonate with retained response to another. J Bone Miner Res 1999; 14(suppl 2):79-84.

8 Arden-Cordone M, Siris ES, Lyles KW, Knieriem A, Newton RA, Schaffer $V$, et al. Antiresorptive effect of a single infusion of microgram quantities of zoledronate in Paget's disease of bone. Calcif Tissue Int 1997;60:415-18.

9 Buckler H, Fraser W, Hosking D, Ryan W, Maricic M, Singer, F et al. Single infusion of zoledronate in Paget's disease of bone: a placebo-controlled, dose-ranging study. Bone 1999;24(suppl):81-5S

10 Green JR, Muller K, Jaeggi KA. Preclinical pharmacology of CGP 42446, a new potent heterocyclic bisphosphonate compound. J Bone Miner Res 1994;9:745-51.

\section{Ayurveda in ankylosing spondylitis and low back pain}

\section{A Falkenbach, $\mathrm{R}$ Oberguggenberger}

$\mathrm{P}$

atients with chronic rheumatic diseases are frequent users of alternative and complementary medicine..$^{1-5}$ In a previous study we found that more than $50 \%$ of patients with ankylosing spondylitis (AS) had experience with such treatments. $^{6}$

Ayurveda, the traditional Indian medical system, is receiving increasing attention from patients and medical doctors in Western nations. Western medicine and Ayurveda have, however, severe difficulties in understanding each other, which impairs the use of Ayurveda as a reasonable "complementary" treatment for patients.

According to the Ayurvedic tridosha teachings rheumatic symptoms result from an inequality and disharmony among the three doshas (humours), in particular from a predominance and dysfunction of the vata dosha. ${ }^{7}$ If this view is applicable to Western patients, one would expect patients with rheumatic disease to show a surplus and overflow of vata constitutional factors (predisposing for rheumatic disease) and patients who are vata types to have more severe symptoms.

The present investigation evaluates the predominant dosha in patients with AS in comparison with patients with (non-inflammatory) low back pain and healthy controls, and the degree of functional impairment in the groups of patients with AS with predominating vata, pitta, or kapha features.

Patients with AS ( $\mathrm{n}=141,114$ male, 27 female, mean age 52 years) and non-inflammatory low back pain $(n=63,35$ male, 28 female, mean age 60 years) presenting for treatment at the Gasteiner Heilstollen Hospital and healthy controls (visitors, staff, $\mathrm{n}=55,32$ male, 23 female, mean age 43 years) were asked to complete a questionnaire deciding which group of features listed in table 1 would, in their own view, best reflect their own personal characteristics. These features are typical

Table 1 Patients were asked to decide which group of features $(A, B$, or $C)$ would in their own view, best reflect their own personal characteristics (according to reference 8, modified, English translation). The denotations vata, pitta, or kapha were not given to the patient

\begin{tabular}{llll}
\hline & Vata A & Pitta B & Kapha C \\
\hline Body build & Slight, thin & Normal & Large \\
Skin & Dry, rough, cool & Soft, warm, pale & Fat, soft, greasy \\
Veins & Easily visible & Slightly visible & Not visible \\
Eyes & Small, dry & Medium, often reddened & Large, moist \\
Sleep & Light and interrupted & Active, short, harmonious & Long and heavy \\
Appetite & Variable & Hearty & Moderate \\
Sweat & Sparse, odourless & Profuse, strong odour & Pleasant odour \\
Memory & Medium & Precise & Good long term memory \\
Language & Fast & Loud and clear & Melodic \\
Character & Shy & Jealous & Caring \\
Behaviour & Unsure & Egoistic & Satisfied with self \\
Dislikes & Cold, wind, dryness & Heat and midday sun & Moisture, cold \\
\hline
\end{tabular}


symptoms and signs of vata, pitta, or kapha as proposed by Rudolph in 1997. ${ }^{8}$ The questionnaire did not give the Ayurvedic denotations to the patients, but named the groups A, B or C. Patients had to decide on one group, which was taken as the individual's predominating vata, pitta or kapha dosha. For quantification of functional impairment of the patients with AS a German version' of the Bath Ankylosing Spondylitis Functional Index $\left(\mathrm{BASFI}^{10}\right)$ was used (with Likert formatted scales).

No predominance of the vata dosha was found in patients with AS or low back pain. The distribution of predominating vata, pitta, or kapha features did not differ (no significant difference in $\chi^{2}$ test) between patients with AS (vata $n=46$ (33\%); pitta $64(45 \%)$, kapha $31(22 \%))$, patients with low back pain (vata $18(29 \%)$, pitta $28(44 \%)$, kapha $17(27 \%)$ ), or healthy controls (vata 18 (33\%), pitta 25 (45\%), kapha 12 $(22 \%))$. Also, patients with AS had the same degree (no significant difference in analysis of variance) of functional impairment whether they showed predominating vata (BASFI, mean (SEM) $3.6(0.3))$, pitta $(3.9(0.29))$, or kapha features $(3.2(0.39))$.

Evidently, the present evaluation failed to show an association between a certain dosha and the manifestation or severity of AS or low back pain. The results do not advocate that Ayurvedic treatments should be employed for AS on the grounds that disharmony in the tridosha system and overflow of vata need correction.

Traditional Indian doctors may maintain that the present form of defining the predominating dosha is an illicit simplification and that extensive diagnostic procedures are needed to establish a proper diagnosis in the sense of Ayurveda. This may be true, but it is up to them to disprove the present conclusion by more sophisticated methods. Here, with our simplified methods we could not find a reasonable foundation for recommending Ayurvedic treatments for patients with the Western diagnosis of ankylosing spondylitis.

\section{Authors' affiliations}

A Falkenbach, R Oberguggenberger, Gasteiner Heilstollen Hospital, Bad Gastein-Boeckstein, Austria

A Falkenbach, Gastein Research Institute, Bad Gastein, Austria

Correspondence to: Dr A Falkenbach, Gasteiner Heilstollen Hospital, A-5645 Bad Gastein-Boeckstein, Austria; falke@gasteiner-heilstollen.com

Accepted 8 July 2002

\section{REFERENCES}

1 Chandola A, Young Y, McAlister J, Axford JS. Use of complementary therapies by patients attending musculoskeletal clinics. J R Soc Med 1999;92:13-16.

2 Ernst E. Usage of complementary therapies in rheumatology: a systematic review. Clin Rheumatol 1998;17:301-5.

3 Ramsey SD, Spencer AC, Topolski TD, Belza B, Patrick DL. Use of alternative therapies by older adults with osteoarthritis. Arthritis Care Res 2001;45:222-7.

4 Rao JK, Mihaliak K, Kroenke K, Bradley J, Tierney WM, Weinberger M. Use of complementary therapies for arthritis among patients of rheumatologists. Ann Intern Med 1999;131:409-16.

5 Resch KL, Hill S, Ernst E. Use of complementary therapies by individuals with "arthritis". Clin Rheumatol 1997;16:391-5.

6 Curda B, Luxl M, Glauninger P, Falkenbach A. Häufigkeit der Anwendung konventioneller und unkonventioneller Therapiemaßnahmen bei Patienten mit Morbus Bechterew. Forsch Komplementärmed Klass Naturheilkd 2000;7:85-8.

7 Ulrich-Merzenich G, Kraft K, Singh LM. Rheumatic diseases in Ayurveda: a historical perspective. Arthritis Rheum 1999:42:1553-5.

8 Rudolph HJ. Gesichtspunkte zu einer Typologie in der ayurvedischen Medizin. In: Bühring M, ed. Naturheilkunde; Grundlagen, Anwendungen, Ziele. München: CH Beck, 1997:76.

9 Ruof J, Sangha O, Stucki G. Evaluation einer deutschen Version des Bath Ankylosing Spondylitis Functional Index (BASFI) und Dougados Functional Index (D-FI). Z Rheumatol 1999;58:218-25.

10 Calin A, Garrett S, Whitelock H, Kennedy LG, O'Hea J, Mallorie P, et al. A new approach to defining functional ability in ankylosing spondylitis: the development of the Bath Ankylosing Spondylitis Functional Index. J Rheumatol 1994;21:2281-5.

\title{
An exceptional radiographic presentation of bilateral insufficiency fractures of the proximal tibia in a patient with rheumatoid arthritis
}

\author{
J Vanhoof, S Landewe, J Vandevenne, P Geusens
}

We report an exceptional radiographic presentation of bilateral insufficiency fractures of the proximal tibia in a 67 year old women with rheumatoid arthritis (RA). The patient developed RA at the age of 55. She was consecutively treated with several disease modifying drugs : parenteral gold (198990), sulfasalazine (1990-91), and methotrexate (MTX; started in 1991 and discontinued in 2001 because of bone marrow suppression); chloroquine was added from 1993 until 1999. Oral corticosteroids (prednisone $5 \mathrm{mg} /$ day) were started in 1990. Because of persistent hydrops of both knees a bilateral chemical synovectomy (osmium acid) was undertaken in 1990. Afterwards three intra-articular infiltrations with depot corticosteroids were given, and the arthritis of the knees resolved. Bone mineral densitometry (BMD) in 1994 showed a T score (compared with young adults) at the lumbar spine of -2.6 standard deviation (SD) and at the femoral neck of $-2.7 \mathrm{SD}$, compatible with osteoporosis. Treatment with calcium supplements and alfacalcidol (50 $\mu \mathrm{g} /$ day) was started as this was the only treatment for glucocorticoid osteoporosis which was reimbursed. Because of further bone loss (follow up BMD still showed a T score at the lumbar spine of $-3.2 \mathrm{SD}$ and at the femoral neck of $-2.8 \mathrm{SD}$ ) cyclical etidronate, the only available bisphosphonate at that time, was given.

In 2000 both knees were examined radiographically because of recurrence of bilateral hydrops. Both knees had an extensive area of periarticular osteoporosis in the tibial plateau and both femoral condyles (fig 1). The osteoporotic areas in the tibial plateaus were demarcated by a focal band-like sclerosis, representing impacted bone trabecula (arrows). Additionally, a fine condensed sclerotic line was seen in the right femoral condyles and less prominently in the left femoral condyles (arrows). Retrospectively, the sclerotic bands appeared to be already present on a radiographic examination in 1994. The diagnosis of old bilateral insufficiency fractures was made and confirmed by 

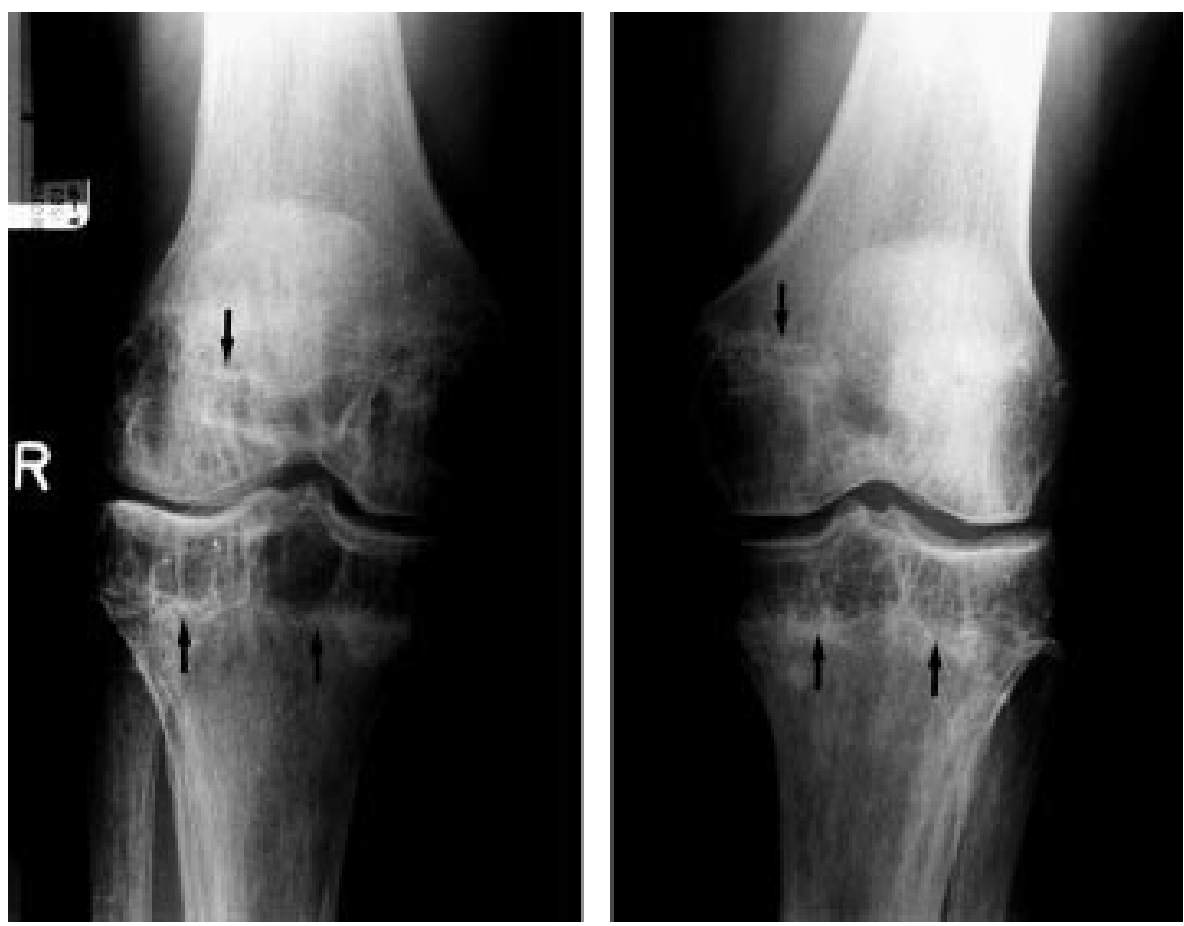

Figure 1 Radiographic examination of both knees. The osteoporotic areas in the tibial plateaus are demarcated by a focal band-like sclerosis representing impacted bone trabecula (arrows).

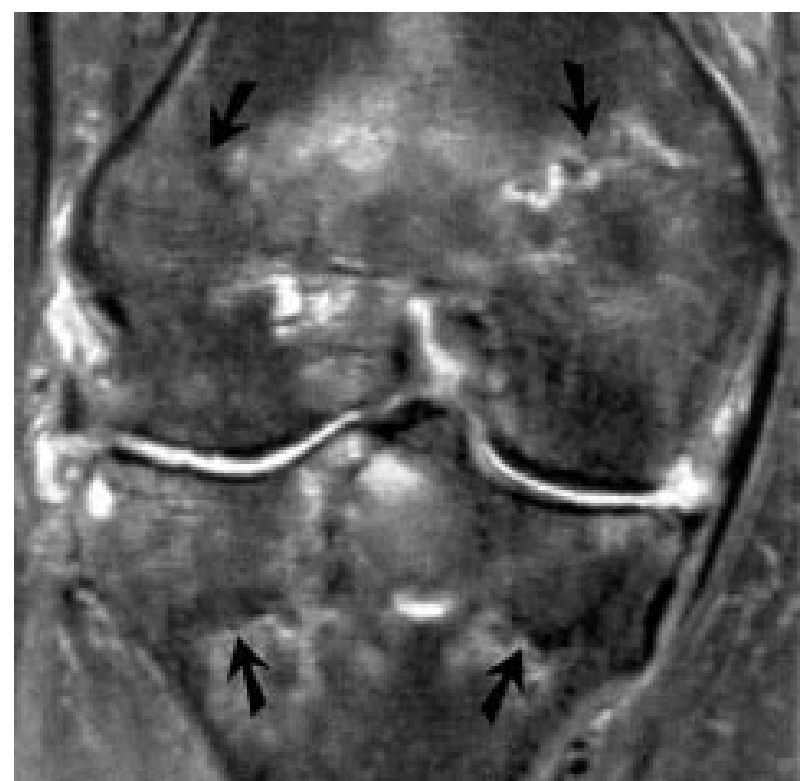

Figure 2 Turbo spin echo $T_{2}$ weighted $M R$ image with fat saturation of the right knee. Arrows indicate a hypointense line associated with only a minimal area of high signal intensity bone marrow oedema, suggesting that these insufficiency fractures are of an older age.

magnetic resonance (MR) imaging. The turbo spin echo $T_{2}$ weighted MR image with fat saturation of the right knee showed features of RA, including multiple high signal intensity subchondral cysts in the femur and tibia, erosion of articular cartilage, meniscal degeneration, and marginal bone erosion. More importantly, a hypointense line was seen in the proximal tibial epiphysis and medial femoral condyl (arrows), representing increased susceptibility from impacted bone trabecula (fig 2 ). This hypointense line was associated with only a minimal area of high signal intensity bone marrow oedema, suggesting that these insufficiency fractures were of an older age. The exceptional radiographic image of both knees thus related to the sclerotic bands, representing insufficiency fractures outlining the periarticular bone density loss due to RA.

\section{DISCUSSION}

Two types of stress fracture can be recognised: fatigue fractures, resulting from the application of abnormal repetitive stress or torque to a bone with normal elastic resistance, and insufficiency fractures, occurring when normal stress is placed upon an abnormal bone. ' In this case the stress fracture was an insufficiency fracture. These insufficiency fractures are more commonly seen in RA and osteoporosis. ${ }^{2}$ Juxta-articular and/or generalised osteopenia caused by extensive rheumatoid involvement, corticosteroid treatment, or relative immobility, is a predisposing factor. ${ }^{3}$ These conditions result in an abnormal bone and were all present in our patient. Additionally, stress fractures due to MTX osteopathy have been reported in long term, low dose MTX treatment for RA. ${ }^{4-6}$ Insufficiency fractures in the knee are, however, a rare complication of MTX treatment in a patient with RA. Most insufficiency fractures during MTX treatment occur in the distal tibia and feet; a localisation in the meta-epiphysial region of the knee is rather exceptional. ${ }^{57}$ Because our patient with RA had apparent osteoporosis and was treated with a combination of corticosteroids and MTX, the cause of the insufficiency fractures cannot be exclusively attributed to the MTX treatment. Any relationship of the insufficiency fractures with the earlier chemical synovectomies is unclear but cannot be excluded.

Although the bilateral tibial stress fractures in our patient were old and at present not symptomatic, a recent stress fracture in the epiphysial region of the proximal tibia can cause knee pain, sometimes with swelling of the joint, mostly activity related and relieved by rest. Because knee pain in a patient with RA with synovitis of the knee joint is not uncommon, the diagnosis of a (acute) stress fracture of the proximal tibia can easily be delayed or missed. ${ }^{18}$ It is therefore likely that stress fractures in RA occur more frequently than commonly thought and are often underdiagnosed and confused with synovitis.

The radiographic presentation of a stress fracture in the epiphysial region of the proximal tibia is a horizontal 
band-like focal sclerosis, representing condensation of trabeculae, mostly without prominent periosteal reaction. Symmetrical involvement, as in our patient, is not unusual. ${ }^{1}$ The findings in our patient with extensive periarticular bone loss (due to rheumatoid knee involvement), demarcated by a contrasting horizontal band-like sclerosis, caused by bilateral stress fractures of the proximal tibial epiphyses, is, however, a rather exceptional radiographic presentation.

\section{Authors' affiliations}

J Vanhoof, S Landewe, Clinical Research Centre for Bone and Joint

Diseases, Biomedical Research Institute, Limburg University Centre,

Diepenbeek, Belgium

J Vandevenne, Department of Radiology, Z.O.L. Campus St Jan,

Schiepse Bos 6, Genk, Belgium

P Geusens, Department of Rheumatology, Academisch Ziekenhuis, Maastricht, The Netherlands

Correspondence to: Dr P Geusens; piet.geusens@ping.be

Accepted 25 June 2002

\section{REFERENCES}

1 Resnick DR, Niwayama G. Diagnosis of bone and joint disorders. Philadelphia: Saunders, 1995:2580-3.

2 Schneider R, Kaye JJ. Insufficiency and stress fractures of the long bones occurring in patients with rheumatoid arthritis. Radiology 1975: 1 16:595-9.

3 Wijnands $M$, Burgers $A$. Stress fracures in long term methotrexate treatment for psoriatic arthritis. Ann Rheum Dis 2001;60:736-8.

4 Semba CP, Mitchell M, Sartoris DJ, Resnick D. Multiple stress fractures in the hindfoot in rheumatoid arthritis. J Rheumatol 1989;16:671-6.

5 Zonneveld IM, Bakker WK, Dijkstra PF, Bos JD, van Soesbergen RM, Dinant HJ. Methotrexate osteopathy in long-term, low-dose methotrexate treatment for psoriasis and rheumatoid arthritis. Arch Dermatol 1996;132:184-7.

6 Maenaut K, Westhovens R, Dequeker J. Methotrexate osteopathy, does it exist? J Rheumatol 1996;23:2156-9.

7 Maenpaa HM, Soini I, Lehto MU, Belt EA. Insuffiency fractures in patients with chronic inflammatory joint diseases. Clin Exp Rheumatol 2002;20:77-9.

8 Shapira D, Scharf Y. Insufficiency fracture of the distal tibia mimicking arthritis in a rheumatoid arthritis patient: the possible role of methotrexate treatment. Clin Exp Rheumatol 1995;13:130-1.

9 Dequeker J, Maenaut K, Verwilghen J, Westhovens R. Osteoporosis in rheumatoid arthritis. Clin Exp Rheumatol 1995;13(suppl 12):S21-6.

\section{Oral contraceptives, rheumatoid arthritis, and androgens}

\section{W H James}

n 1993 I reviewed the evidence that rheumatoid arthritis (RA) is more common in women than men; that remissions commonly occur in pregnancy; and that relapses commonly occur post partum. ${ }^{1}$ These features suggested involvement of the sex hormones, and in view of the lack of persuasive evidence relating high oestrogen levels to RA, I suggested that one cause might be low androgen levels. Cross sectional studies relating oral contraceptives (OCs) to RA (despite large numbers of cases and carefully selected controls) had proved inconclusive (not to say contradictory). So I reconciled these data with my hypothesis by offering grounds for supposing that OC use is (initially) a marker for high steroid hormone levels. It is worth repeating the argument because, in principle, it might explain contradictory findings relating RA to behavioural risk factors other than OC use (for example, smoking and alcohol consumption). I cited evidence for three propositions-namely, that

- Low androgen concentrations are a cause of RA

- Women who choose OCs initially have higher androgen concentrations than other women

- A pharmacological effect of OCs is to lower women's androgen concentrations.

The suggestion is that in cross sectional studies, androgens act as confounders between OC use (treated as a risk factor) and RA. Indeed, the principle has been generalised to suggest that gonadal hormones confound between a number of behavioural risk factors (OC use, smoking, alcohol consumption, vasectomy, induced abortion) and a number of disease conditions that are known or suspected to be caused by high or low hormone levels. ${ }^{2}$

The point of these comments will now become clear. In a prospective study, Drossaers-Bakker et al found that despite the number of reports from cross sectional studies of a negative (protective?) association between OC use and RA, OC use does not significantly influence outcome in long term RA. ${ }^{3}$ I suggest that this is as would have been predicted on the basis of my hypothesis.
In my original paper ${ }^{1}$ I cited persuasive evidence that both male and female patients with RA have lower androgen levels than healthy controls; and this conclusion has been corroborated by subsequent evidence. ${ }^{45}$ However, the possibility may be acknowledged that low androgen levels are markers (rather than causes) of RA. But it is now becoming clear that (counter to this possibility), administration of androgens to patients with RA ameliorates the condition. ${ }^{67}$ There may be several agents which cause or exacerbate RA: I suggest that in some cases, low androgen levels are one of them.0

\section{Authors' affiliations}

W H James, The Galton Laboratory, University College London, Wolfson House, 4 Stephenson Way, London NW 12 HE, UK

Correspondence to: Dr James

Accepted 22 July 2002

\section{REFERENCES}

1 James WH. Rheumatoid arthritis, the contraceptive pill, and androgens. Ann Rheum Dis 1993;52:470-4

2 James WH. Hypothesis: gonadal hormones act as confounders in epidemiological studies of the associations between some behavioural risk factors and some pathological conditions. J Theor Biol 2001;209:97-102.

3 Drossaers-Bakker KW, Zwinderman AH, van Zeben D, Breedveld FC, Hazes JMW. Pregnancy and oral contraceptive use do not significantly influence outcome in long term rheumatoid arthritis. Ann Rheum Dis 2002:61:405-8

4 Masi AT. Sex hormones and rheumatoid arthritis: cause or effect relationships in a complex pathophysiology? Clin Exp Rheumatol $1995 ; 13: 227-40$

5 Tengstrand B, Carlstrom K, Hafstrom I. Bioavailable testosterone in men with rheumatoid arthritis: high frequency of hypogonadism. Rheumatology 2002;41:285-9.

6 Booij A, Biewenga-Booij CM, Cornelis C, Jacobs JWG, Bijlsma JWJ. Androgen as adjuvant treatment in postmenopausal female patients with rheumatoid arthritis. Ann Rheum Dis 1996;55:811-15.

7 Cutolo $M$. Sex hormone adjuvant therapy in rheumatoid arthritis. Rheum Dis Clin North Am 2000;26:881-95. 


\title{
Anti-tumour necrosis factor $\alpha$ monoclonal antibody therapy for recalcitrant cerebral vasculitis in a patient with Behçet's syndrome
}

\author{
G Licata, A Pinto, A Tuttolomondo, A Banco, F Ciccia, A Ferrante, G Triolo
}

Ann Rheum Dis 2003;62:280-281

B ehçet's disease (BD) is a relapsing systemic vasculitis of unknown definite cause, mainly characterised by recurrent oral and genital ulceration, uveitis, skin lesions, and arthritis. It is also one of the best recognised condition known to cause vasculitis in the central nervous system (CNS), presenting as one of the most devastating manifestations of the disease.

Corticosteroids and immunosuppressive agents are the preferred drugs in the treatment of both primary and secondary CNS vasculitis. Immunosuppressive agents (for example, azathioprine, cyclosporin, cyclophosphamide, and chlorambucil), however, given alone or in different combinations, have not been shown to prevent the development of neurological complications of the disease, to reduce its exacerbations, or stop its progression.

The aetiopathogenesis of BD has not yet been fully elucidated; however, increased concentrations of tumour necrosis factor $\alpha$ (TNF $\alpha)$ and soluble TNF receptors have been found in the serum of patients with active disease.

Therapeutic TNF blockade has been successfully used for treating various conditions in which TNF seems to be of importance in mediating inflammation (for example, Crohn's disease, rheumatoid arthritis). ${ }^{2}$ We and others have also presented data on the efficacy of anti-TNF therapy for severe recalcitrant manifestations of $\mathrm{BD} .^{3-5}$ In this report we describe the use of the anti-TNF $\alpha$ chimeric monoclonal antibody, infliximab (Remicade, Centocor Inc, Malvern, PA, Schering Plough SpA, Italy), in a patient with BD who had severe CNS disease refractory to standard treatment.

\section{CASE REPORT}

A 59 year old woman with a history of recurrent oral aphthous ulcers, chronic erythema nodosum, superficial thrombophlebitis, and arthritis was admitted in October 2001 for a sudden occurrence of CNS disease. She presented findings of pyramidal involvement and hemiplegia. Results of a chest $x$ ray examination and urine analysis were normal, blood $\mathrm{pH}$ and $\mathrm{PO}_{2}$ were in the normal range. White blood cell count was $5.6 \times 10^{9} /$, erythrocyte sedimentation rate (ESR) $104 \mathrm{~mm} / 1 \mathrm{st} \mathrm{h}$, and $\mathrm{C}$ reactive protein (CRP) $54 \mathrm{mg} / \mathrm{l}$. Antinuclear, antidsDNA, antineutrophil cytoplasmic, and anticardiolipin antibodies and lupus anticoagulant were negative. Cerebral magnetic resonance imaging (MRI) showed two (corticalsubcortical and para-sagittal) high signal intensity lesions in the frontal lobe and another (cortical-subcortical) lesion in the temporal lobe (figs IA and B). Intravenous methylprednisolone (l g/day for three days) and cyclophosphamide (l $\mathrm{g} / \mathrm{m}^{2}$ ) was started, followed by oral prednisone ( $50 \mathrm{mg} /$ day). After four weeks intravenous methylprednisolone and cyclophosphamide were repeated as previously.

In December 2001 she was readmitted for the occurrence of severe CNS manifestations. She was lethargic. Although a partial resolution of the previous lesions was present at MRI, new cortical-subcortical lesions in parietal lobes and corticalsubcortical lesions in the frontal lobe were seen (figs IC and D). An infusion protocol with infliximab was designed and
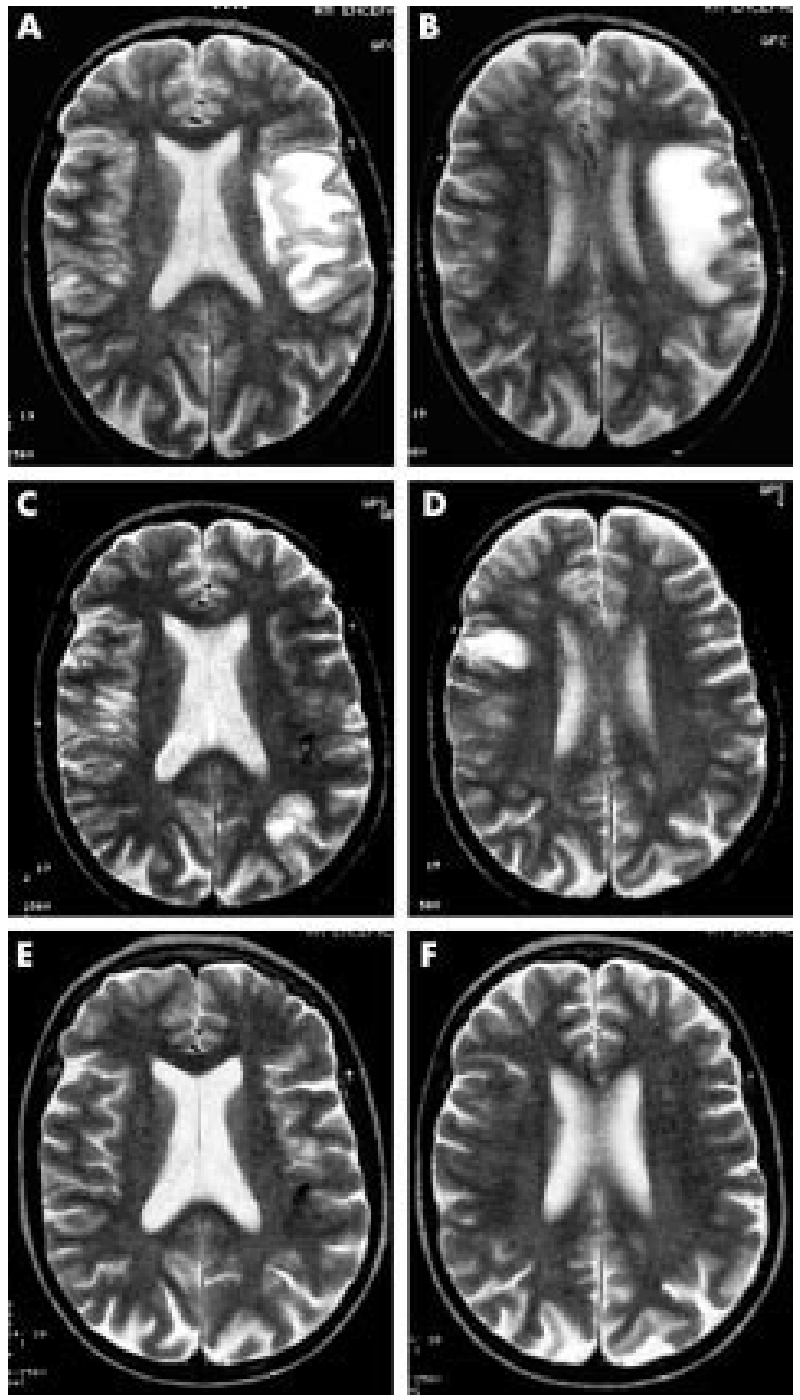

Figure 1 Axial $\mathrm{T}_{2}$ weighed sequence MRI (0.5 T; TR (repetition time) $2500 \mathrm{~ms}$; TE (echo time) $25 \mathrm{~ms}$ ) at admission (A, B), after intravenous methylprednisolone and cyclophosphamide (C, D), and after anti-TNF therapy $(E, F)$.

approved by the Department of Medicine Institutional Board and informed consent was obtained from the patient. The patient was infused with infliximab $5 \mathrm{mg} / \mathrm{kg}$ at weeks 0,2 , and 6. Infliximab was administered by two-hour infusion and the patient observed for a further two hours; no adverse effect was seen. An improvement in symptoms was noticed within 24 hours after receiving the first infusion and remained stable throughout the observation period. In particular, her wellbeing improved markedly. Cerebral MRI performed a week after the infusion showed a complete resolution of signal 
abnormalities (figs IE and F). After the second infusion she had a complete remission of all signs and symptoms of neurological involvement. No changes (either clinical or instrumental) were present after one month's observation (not shown). The ESR was $15 \mathrm{~mm} / \mathrm{lst} \mathrm{h}$ and CRP $3.8 \mathrm{mg} / \mathrm{l}$ and they have remained normal until now.

\section{DISCUSSION}

This is the first report, to our knowledge, of the treatment of cerebral vasculitis in $\mathrm{BD}$ with anticytokine-specific treatment. Indeed, anti-TNF therapy has been successfully used in other forms of vasculitis. ${ }^{67}$ Treatment with infliximab led to a complete remission of all disease manifestations in our patient and there was no recurrence for up to eight weeks after the last infusion. This effect appears to be remarkable as standard treatment had failed in our patient. No side effects were seen in this short term observation period. Our results may indicate also a possible role for anti-TNF therapy in primary cerebral vasculitis or in CNS involvement in the course of other immunological conditions in which $\mathrm{TNF} \alpha$ is considered to play a part.

\section{Authors' affiliations}

G Licata, A Pinto, A Tuttolomondo, Dipartimento Biomedico di

Medicina Interna e Specialistica, Division of Internal Medicine, University

of Palermo, Italy
A Banco, Istituto di Radiologia, University of Palermo, Italy F Ciccia, A Ferrante, G Triolo, Dipartimento Biomedico di Medicina Interna e Specialistica, Rheumatology and Clinical Immunology Section, University of Palermo, Italy

Correspondence to: Professor G Triolo, Istituto di Clinica Medica, piazza delle Cliniche 2, 90127 Palermo, Italy; e-mail triolog@tiscalinet.it

Accepted 5 August 2002

\section{REFERENCES}

1 Turan B, Galati H, Erdi H, Gurler A, Michel BA, Villiger PM. Systemic levels of the T cell regulatory cytokines IL-10 and IL-12 in Behçet's disease: soluble TNFR-75 as a biological marker of disease activity. J Rheumatol 1997;24:128-32.

2 Illei GG, Lipsky PE. Novel, non-antigen specific, therapeutic approach to autoimmune/inflammatory diseases. Curr Opin Immunol 2000; 12:712-18

3 Goossens PH, Verburg RJ, Breedveld FC. Remission of Behçet's syndrome with tumor necrosis factor alpha blocking therapy. Ann Rheum Dis 2001;60:637

4 Sfilakis PP, Theodossiadi PG, Katsiari CG, Kaklamanis P, Markomichelakis NN. Effect of infliximab on sight-threatening panuveitis in Behçet's disease. Lancet 2001;358:295-6.

5 Triolo G, Vadalà $M$, Accardo-Palumbo A, Ferrante A, Ciccia F, Giardina $E$, et al. Anti-tumor necrosis factor monoclonal antibody treatment for ocular Behçet's disease. Ann Rheum Dis 2002;61:560-1. 6 Stone JH, Uhlfelder ML, Hellmann DB, Crook S, Bedox NM, Hoffman GS. Etanercept combined with conventional treatment in Wegener's granulomatosis: a six month open-label trial to evaluate safety. Arthitis Rheum 2001;44:1149-54

7 Booth AD, Jefferson HJ, Ayliffe Y, Andrews PA, Jayne DR. Safety and efficacy of TNF $\alpha$ blockade in relapsing vasculitis. Ann Rheum Dis 2002:61:559.

\section{Tubulointerstitial nephritis and uveitis syndrome: a diagnosis that should be considered by rheumatologists}

\section{G S Habib, D Kushnir, M Hyams, V Frajewicki}

Ann Rheum Dis 2003;62:281-282

T bulointerstitial nephritis and uveitis (TINU) syndrome is an entity known mainly to the nephrologists. It has similar features to some of the rheumatic diseases, especially Sjögren's syndrome and lupus. However, many rheumatologists are not familiar with this entity. TINU syndrome should be considered in the differential diagnosis in patients with renal and/or ocular involvement.

\section{CASE REPORT}

A 56 year old woman was referred to the rheumatologist for the evaluation of musculoskeletal pain, positive antinuclear antibody (ANA), and renal failure. She reported diffuse musculoskeletal pain for the past two months, with worsening of these symptoms during the past week. She denied morning stiffness or swelling of the joints. One month ago she also had sore eyes with some redness and was evaluated by an ophthalmologist, who prescribed "eye drops" with good results. She also had dry cough during the past month. Otherwise she had no chronic health problems. She denied dry mouth, photosensitivity, alopecia, oral or genital ulcers, Raynaud's phenomenon, or swallowing problems. For the musculoskeletal pain she took simple analgesics only. A physical examination showed blood pressure 110/70 mm Hg, and diffuse trigger points without joint swelling. There was no organomegaly or lymphadenopathy. Skin was normal. Sclera and conjunctiva looked normal. Lungs were clear.

Laboratory studies showed a white cell count of $8.7 \times 10^{9} / 1$, haemoglobin $103 \mathrm{~g} / \mathrm{l}$, packed cell volume 0.33 , platelets $224 \times 10^{9} / 1$, neutrophils 0.66 , lymphocytes 0.22 , urea $8.3 \mathrm{mmol} / \mathrm{l}$ (normal 2.5-6.0), serum creatinine $140 \mu \mathrm{mol} / \mathrm{l}$ (serum creatinine was normal one year ago), sodium $134 \mathrm{mmol} / \mathrm{l}$, potassium $3.8 \mathrm{mmol} / \mathrm{l}$, calcium $2.3 \mathrm{mmol} / \mathrm{l}$, phosphorus 1.00 $\mathrm{mmol} / \mathrm{l}$, total protein $77 \mathrm{~g} / \mathrm{l}$, globulins $37 \mathrm{~g} / \mathrm{l}$, uric acid 150 $\mu \mathrm{mol} / \mathrm{l}$ (normal 140-340), glucose $4.8 \mathrm{mmol} / \mathrm{l}$. Liver function tests, prothrombin time, partial thromboplastin time, and fibrinogen were normal. A Coombs test was negative. Erythrocyte sedimentation rate (ESR) (Westergren) was 85 $\mathrm{mm} / \mathrm{lst} \mathrm{h}, \mathrm{C}$ reactive protein $570 \mathrm{mg} / \mathrm{l}$ (normal 0-50), ANA positive, antibodies to DNA, SS-A, SS-B, RNP, Sm, Jo-1, Scl70, HIV, HCV, glomerular basement membrane, and cardiolipin were all negative. Antibodies to brucella, chlamydia, EpsteinBarr virus, cytomegalovirus, and toxoplasma were negative for acute infection. Rheumatoid factor (RF), hepatitis B surface antigen, and antineutrophil cytoplasmic antibodies (ANCA) were negative also. C3 was $1.4 \mathrm{~g} / \mathrm{l}$ (normal 0.9-1.8), C4 $0.4 \mathrm{~g} / \mathrm{l}$ (normal 0.1-0.4), antistreptolysin O antibody titre $98 \mathrm{IU} / \mathrm{ml}$ (normal 0-200), serum IgG 20.7 g/l (normal 7.00-15.00), IgA $3.47 \mathrm{~g} / \mathrm{l}$ (normal 1.30-4.00), IgM $3.34 \mathrm{~g} / \mathrm{l}$ (normal 0.50-2.00). Immunoelectrophoresis was normal. Angiotensin converting enzyme (ACE) level was normal. Urine analysis showed glucose $5.6 \mathrm{mmol} / \mathrm{l}$, protein $250 \mathrm{mg} / \mathrm{l}, \mathrm{pH} 7.0$, specific gravity 1.01, erythrocytes $4-6 /$ high power field (hpf), leucocytes 1-3/ hpf, granular casts $2-4 / \mathrm{hpf}$, and few epithelial casts. Twenty four hour urine protein was $1.39 \mathrm{~g} /$ day, creatinine clearance $0.52 \mathrm{ml} / \mathrm{s}$, Schirmer test $5 \mathrm{~mm}$ (during five minutes). Rose bengal staining was negative. Chest radiographs and electrocardiograms were normal. 
Repeated tests a few days later disclosed deterioration of kidney functions (creatinine $190 \mu \mathrm{mol} / \mathrm{l}$ ) and the patient was admitted to the nephrology department. The patient had a kidney biopsy that showed dense mononuclear infiltrate in the stroma, mainly lymphocytes and plasma cells. Few eosinophils and neutrophils were also seen. Some of the tubuli were damaged. A non-caseating granuloma was seen. About $25 \%$ of the stroma was sclerotic. Glomeruli were normal. Immunofluorescence studies showed minimal granular deposition of C3 in the wall of the tubuli but was otherwise negative. An eye examination showed "snowballs" in the vitreous near the inferoposterior part of the retina consistent with intermediate uveitis. The anterior chamber was normal. There was no evidence of vasculitis. Computed tomography (CT) of the chest and pulmonary function tests were normal. A lip biopsy was normal.

The patient was diagnosed with TINU syndrome and treatment was started with $40 \mathrm{mg} / \mathrm{d}$ of prednisone. An ophthalmological evaluation one week later was completely normal and serum creatinine was $140 \mu \mathrm{mol} / \mathrm{l}$. After two months of systemic corticosteroid treatment prednisone was stopped with serum creatinine $120 \mu \mathrm{mol} / \mathrm{l}$, creatinine clearance 0.86 $\mathrm{ml} / \mathrm{s}$, and 24 -hour urine protein $0.59 \mathrm{~g} /$ day. Three months later the patient was admitted to the ophthalmology department owing to recurrence of intermediate uveitis with similar findings on ophthalmological evaluation as before. Her symptoms of musculoskeletal pain and cough were much less than before. A Schirmer test $6 \mathrm{~mm}$ (during five minutes) and a rose bengal test were negative. Complete blood count was normal, creatinine $110 \mu \mathrm{mol} / \mathrm{l}$, urea $6.4 \mathrm{mmol} / \mathrm{l}$ (normal 2.5-6.0), ESR $10 \mathrm{~mm} / \mathrm{lst}$ h, C3 $1.3 \mathrm{~g} / \mathrm{l}, \mathrm{C} 40.2 \mathrm{~g} / \mathrm{l}$, RF negative, ANA positive with negative panel. Repeated chest radiographs and ACE level were normal. Spot urine analysis was negative for glucose, ketones, and leucocytes with a $\mathrm{pH}$ of 6.0, specific gravity 1.026, and urine protein $300 \mathrm{mg} / \mathrm{l}$. The patient was treated successfully with topical and subtenon corticosteroids.

\section{DISCUSSION}

The findings for our patient do not satisfy the criteria for the diagnosis of either lupus or Sjögren's syndrome. Lack of pulmonary findings on CT scan and pulmonary function tests, no lymphadenopathy, and skin involvement with normal ACE levels do not strongly support the diagnosis of sarcoidosis. On the other hand, the findings best fit a diagnosis of TINU syndrome.

TINU syndrome was first reported by Dobrin et al in $1975 .{ }^{1}$ An excellent major review of world publications on TINU syndrome that was published recently identified 133 cases. ${ }^{2}$ The female:male ratio is nearly $3: 1$. Initial symptoms occur mostly in adolescence or adulthood but it has also been reported in the elderly. These symptoms/signs include fever, weight loss, fatigue, malaise, anorexia, weakness, and abdominal or flank pain. Seventeen per cent of the patients had arthralgia or myalgia. The most common ocular symptoms are eye pain and redness, decreased vision, and photophobia. The uveitis is usually anterior and bilateral, but all chambers may be affected. It may precede, follow, or occur concomitantly with the renal disease. Proximal and/or distal tubular dysfunction are the prominent features of the tubulointerstitial component of the disease. These patients may also develop mild to severe renal disease. Histologically, there is evidence of acute interstitial nephritis and tubular lesions with or without eosinophils. Non-caseating granulomata could also be seen. The infiltrate is of mononuclear cells, mainly CD4 positive T cells. The pathogenesis of the disease is unknown. It is believed that $\mathrm{T}$ cell mediated immunity has an important role. A recently identified autoantibody directed to renal tubular cells ${ }^{3}$ and hyperglobulinaemia also support a humoral role. Laboratory features of the disease include anaemia, increased ESR, raised $\mathrm{C}$ reactive protein, hypergamaglobulinaemia and increased $\beta_{2}$ microglobulin in the urine. Some of the patients had positive serology, including ANA, ${ }^{45}$ anti-DNA antibodies, ${ }^{6} \mathrm{RF}^{1}{ }^{1}$ anticardiolipin antibodies, ${ }^{7}$ cANCA, ${ }^{8}$ and low complement. ${ }^{9}$ The uveitis usually responds to local or systemic steroids, but recurrence or chronicity is not uncommon. The interstitial nephritis also responds favourably to corticosteroids and it may regress spontaneously.

\section{Authors' affiliations}

G S Habib, Department of Internal Medicine B, Lady Davis Carme Medical Centre, Faculty of Medicine, Technion, Israel Institute of Technology, Haifa, Israel

D Kushnir, V Frajewicki, Department of Nephrology, Lady Davis

Carmel Medical Centre

M Hyams, Department of Ophthalmology, Lady Davis Carmel Medica Centre

Correspondence to: $\mathrm{Dr}$ G S Habib, Department of Internal Medicine B Carmel Medical Centre, 7 Michal Street, Haifa 34362, Israel; gshabib62@yahoo.com

Accepted 24 July 2002

\section{REFERENCES}

1 Dobrin RS, Vernier RL, Fish AL. Acute eosinophylic interstitial nephritis and renal failure with bone marrow-lymph node granulomas with anterior uveitis. A new syndrome. Am J Med 1975;59:325-33.

2 Mandeville JT, Levinson RD, Holland GN. The tubulointerstitial nephritis and uveitis syndrome. Surv Ophthalmol 2001;46:195-208.

3 Wakaki H, Sakamoto H, Awazu M. Tubulointerstitial nephritis and uveitis syndrome with autoantibody directed to renal tubular cells. Pediatrics 2001; 107:1443-6.

4 Auclin F, Bodard-Rickelman E, Vignal-Clermont C, Thomas D. Interstitial tubulo-nephritis and uveitis (TINU syndrome). Apropos of case. J Fr Ophthalmol 1989;12:307-11

5 Gianviti A, Greco M, Barsotti P, Rizzoni G. Acute tubulo-interstitial nephritis occurring with 1 -year lapse in identical twins. Pediatr Nephrol 1994;8:427-30

6 Kikkawa Y, Sakurai M, Mano T, Hirabayashi K, Kitagawa T. Interstitial nephritis with concomitant uveitis. Report of two cases. Contrib Nephrol 1975;4:1-11

7 Gion N, Stavrou P, Foster CS. Immunomodulatory therapy for chronic tubulointerstitial nephritis-associated uveitis. Am J Ophthalmol 2000; 129:764-8

8 Chen HC, Sheu MM, Tsai JH, Lai YH. Acute tubulo-interstitial nephritis and uveitis with anti-neutrophil cytoplasmic antibodies in an adult: an autoimmune disorder? Nephron 1998;78:372

9 Conz PA, Milan M, Bragantini L, La-Greca G, Bevilacqua BA. TINU syndrome associated with reduced complement level. Nephron 2001:89:340-1. 


\title{
Cerebral calcifications in an elderly lupus patient
}

\author{
V Filloux, H Marotte, P Miossec
}

Ann Rheum Dis 2003;62:283-284

$\mathrm{T}$ he diagnosis of central nervous system (CNS) manifestations in systemic lupus erythematous (SLE) is often difficult. These manifestations may be explained by a number of aetiologies. Here, we discuss the possible role of Fahr's disease in an elderly patient with lupus CNS manifestations. Fahr's disease is characterised by idiopathic, sporadic, extensive, and symmetric striatopallidodentate calcifications, with calcium deposits in the cerebral basal ganglia, dentate nuclei, and both the cerebral and cerebellar cortex. ${ }^{1}$ It is often asymptomatic and discovered during brain imaging. ${ }^{2}$ However, it has been associated with neurological manifestations including hemichorea, Parkinson's disease, epilepsy, and dementia. ${ }^{3}$

\section{CASE REPORT}

A 76 year old woman was admitted to the hospital in February 1998 for a non-destructive inflammatory polyarthritis, which had started in 1997. At that time, she developed a right pleural effusion with a non-regenerative anaemia and neutropenia. In addition, she had high levels of antinuclear antibody (1/1024 homogeneous) but no dsDNA. No lupus anticoagulant or cardiolipin antibodies were found. Complement was normal. The diagnosis of SLE was made.

She improved rapidly with steroids $(40 \mathrm{mg}$ /day which were rapidly reduced and stopped) and long term methotrexate ( $7.5 \mathrm{mg} /$ week) treatment. In August 2000 she was sent back to the hospital for neurological symptoms with a progressive loss of cognitive capacities and a right motor deficit with a pyramidal syndrome. An electroencephalogram showed signs of localised epilepsy with a left temporo-occipital focus. Brain computed tomographic scan did not show any major ischaemic area but important calcifications compatible with Fahr's disease (fig lA). Magnetic resonance imaging (MRI) of the brain showed these calcifications in association with cortical atrophy (fig $1 \mathrm{~B}$ ) and hyperintense $\mathrm{T}_{2}$ signals in the peri- ventricular white matter compatible with vascular manifestations either non-specific or the consequence of vasculitis (fig lC). Cerebrospinal fluid examination showed normal cell counts and a protein level of $0.68 \mathrm{~g} / \mathrm{l}$ (normal $0.2-0.4$ ). She had no obvious cardiovascular risk factors (normal blood pressure, no smoking, and normal cholesterol level).

She was seen again in December 2000. The clinical picture had further deteriorated with an important cognitive impairment with dementia and tetraplegia. Laboratory and MRI findings were similar. Cervical MRI was not performed. Steroids were increased from 10 to $30 \mathrm{mg} /$ day for 15 days, but this had no effect on the clinical picture. She continued to deteriorate until death. A postmortem examination was not performed.

\section{DISCUSSION}

This observation emphasises the complexity of CNS manifestations in a patient with SLE, ${ }^{4}$ which are multifactorial, combining thrombotic events, hypertension vasculitis or complications of treatment. ${ }^{5}$ Here, the age of the patient, the absence of antiphospholipid antibodies, often associated with thromboembolic events, and the absence of other concomitant signs of lupus activity do not support the diagnosis of cerebral lupus. In addition, MRI showed only localised manifestations unable to explain the whole picture. It is becoming clear that non-specific vascular cerebral disease is very common at a late stage of SLE as a consequence of both prolonged vessel inflammation and steroid treatment. The first report of intracerebral calcifications and cerebral lupus was that of a child in $1981 .{ }^{6}$ In a extended study, intracerebral calcifications were found in eight of 27 young adult patients with cerebral lupus. ${ }^{7}$ In that study no relationship was observed between these calcifications and the neurological presentation. In our case, the patient was older and calcifications were specifically localised in basal ganglia. Although parathyroid disorders are
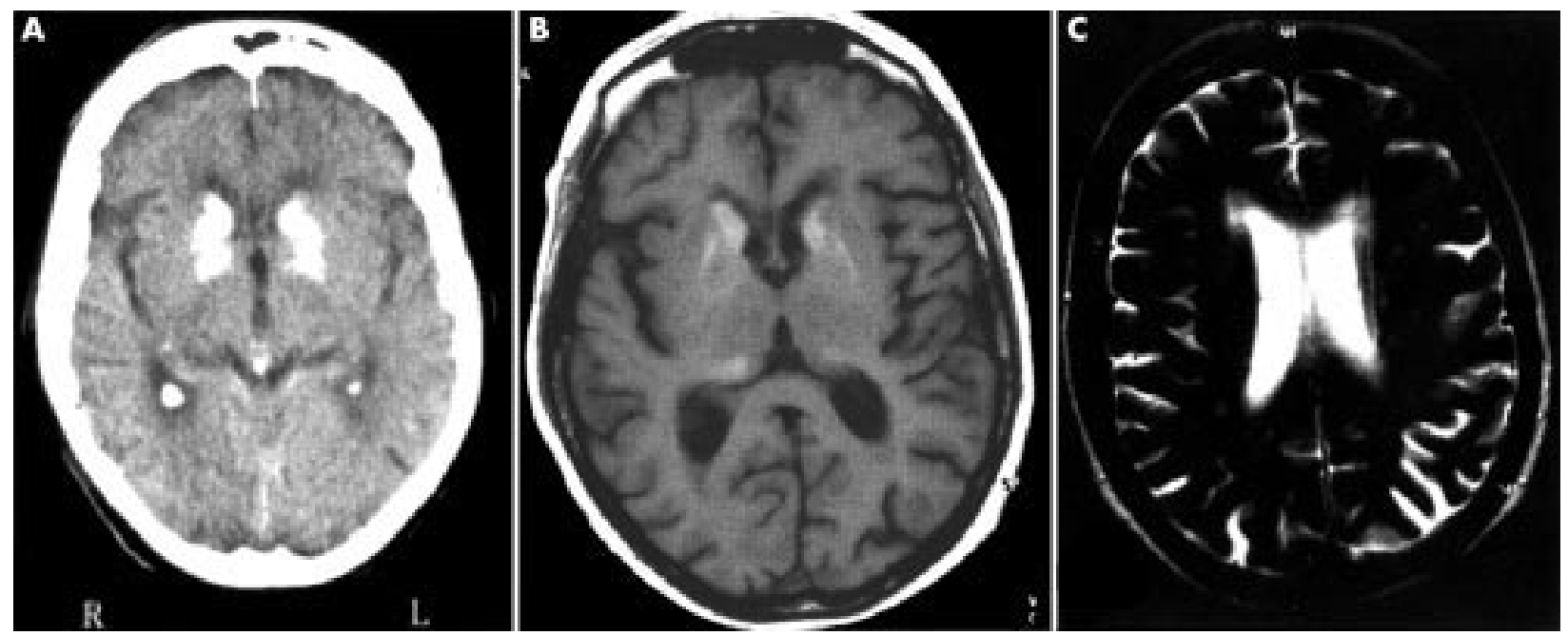

Figure 1 Basal ganglia calcifications compatible with Fahr's disease. (A) Brain computed tomographic scan image without injection showing no major ischaemic area but important calcifications in the basal ganglia. (B) Transverse brain section on $T_{1}$ weighted MR images. $T_{1}$ weighted MRI shows these calcifications in the basal ganglia in association with cortical atrophy. (C) Transverse brain section on $T_{2}$ weighted MR images. $T_{2}$ weighted MRI shows hyperintense signals in the periventricular white matter compatible with vascular manifestations either non-specific or the consequence of vasculitis. 
commonly associated with these calcifications, ${ }^{8}$ we found no support for any parathyroid dysfunction. Similar CNS manifestations with multifocal small vessel involvement were seen in a patient with SLE with typical signs of Fabry's disease. ${ }^{9}$

In conclusion, the link between cerebral calcifications and CNS manifestations in SLE remains unclear. In particular, the effect of local inflammation may represent a cofactor for the induction of cerebral calcifications. Similar observation has been made in the case of muscle inflammation.

\section{Authors' affiliations}

V Filloux, H Marotte, P Miossec, Departments of Immunology and Rheumatology, Hôpital Edouard Hérriot, Lyon, France

Correspondence to: Professor P Miossec, Clinical Immunology Unit, Departments of Immunology and Rheumatology, Hôpital Edouard Hérriot, 69437 Lyon Cedex 03, France; miossec@univ-lyon 1.fr

Accepted 23 July 2002

\section{REFERENCES}

1 Manyam BV, Walters AS, Narla KR. Bilateral striopallidodentate calcinosis: clinical characteristics of patients seen in a registry. Mov Disord 2001;16:258-64.

2 Avrahami E, Cohn DF, Feibel M, Tadmor R. MRI demonstration and CT correlation of the brain in patients with idiopathic intracerebral calcification. J Neurol 1994;241:381-4.

3 Manyam BV, Walters AS, Keller IA, Ghobrial M. Parkinsonism associated with autosomal dominant bilateral striopallidodentate associated with autosomal dominant bilateral striopallid
calcinosis. Parkinsonism Relat Disord 2001:7:289-95.

4 Sanna G, Piga M, Terryberry JW, Peltz MT, Giagheddu S, Satta L, et al. Central nervous system involvement in systemic lupus erythematosus: cerebral imaging and serological profile in patients with and withou overt neuropsychiatric manifestations. Lupus 2000;9:573-83.

5 Zonana-Nacach A, Barr SG, Magder LS, Petri M. Damage in systemic lupus erythematosus and its association with corticosteroids. Arthritis Rheum 2000;43:1801-8.

6 Anderson JR. Intracerebral calcification in a case of systemic lupus erythematosus with neurological manifestations. Neuropathol App Neurobiol 1981:7:161-6.

7 Raymond AA, Zariah AA, Samad SA, Chin CN, Kong NC. Brain calcification in patients with cerebral lupus. Lupus 1996:5:123-8.

8 el Maghraoui A, Birouk N, Zaim A, Slassi I, Yahyaoui M, Chkili T. Fahr syndrome and dysparathyroidism. 3 cases. Presse Med syndrome and dysparc

9 Rahman P, Gladman DD, Wither J, Silver MD. Coexistence of Fabry's disease and systemic lupus erythematosus. Clin Exp Rheumato $1998 ; 16: 475-6$

\title{
Response of mononuclear cells to lipopolysaccharide and CpG oligonucleotide stimulation: possible additive effect in rheumatoid inflammation
}

\author{
B Tolusso, M Fabris, E Di Poi, R Assaloni, P Tomietto, G F Ferraccioli
}

$\mathrm{T}$ he relationship between infections and autoimmune inflammation is of paramount importance in all chronic inflammatory diseases. ${ }^{1}$ The crucial step is the interaction between the Toll-like receptor family and bacterial components, which can lead to activation of phagocytic and dendritic cells. ${ }^{2}{ }^{3}$ Whether bacterial components may indeed reactivate autoimmune inflammation is at present still unclear. However, it is well known that oligonucleotides containing unmethylated $\mathrm{CpG}$ sequences (CpG-ODN), while stimulating bacterial DNA, might have immunostimulatory activity. ${ }^{3}$ We have recently presented data suggesting that moderate infections such as upper-lower respiratory or urinary tracts infections may reactivate rheumatoid arthritis (RA) in patients receiving etanercept.

There is evidence in experimental animals ${ }^{23}$ that Toll-like receptor 4 (activated by lipolysaccharide (LPS)) can induce a cytokine response, whereas Toll-like receptor 9 , activated by CpG-ODN, induces mononuclear cell activation in a much more restricted manner. Especially in humans, B cells seem to be the more sensible to bacterial DNA activation, with antibody and autoantibody production.

In this study we were interested to determine whether and how CpG-ODN might stimulate mononuclear cells from
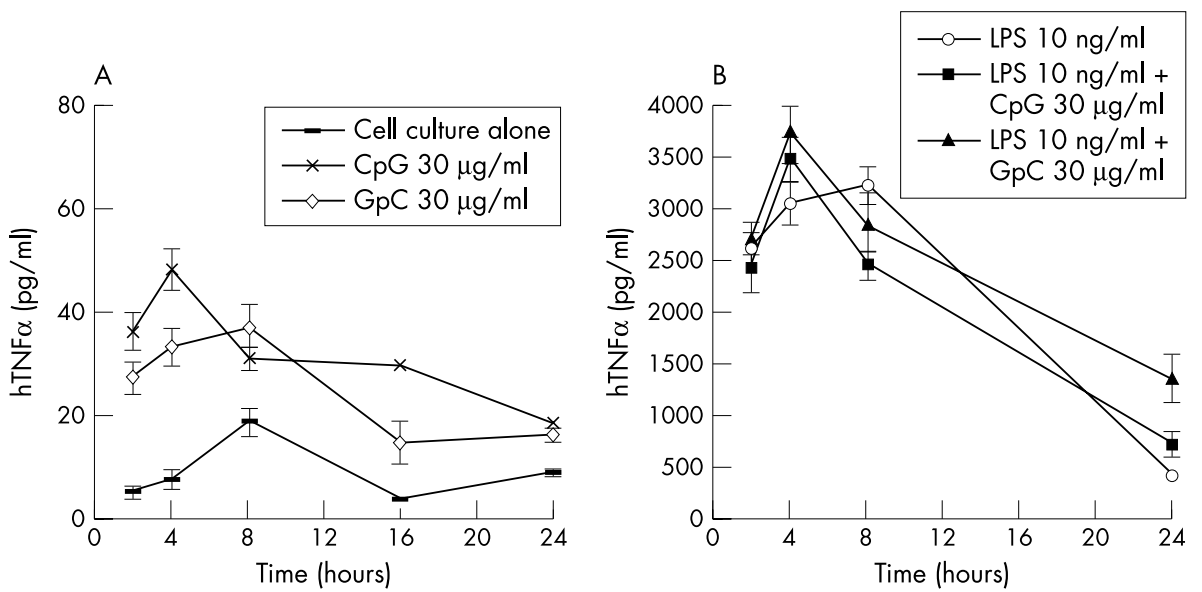

Figure 1 Mononuclear cells from five patients with RA were stimulated with unmethylated CpG-ODN (30 $\mathrm{gg} / \mathrm{ml})$, unmethylated GpC-ODN $(30 \mathrm{\mu g} / \mathrm{ml})$, LPS $(10 \mathrm{ng} / \mathrm{ml})$, LPS $(10 \mathrm{ng} / \mathrm{ml})$ plus unmethylated CpG-ODN $(30 \mathrm{\mu g} / \mathrm{ml})$, or LPS $(10 \mathrm{ng} / \mathrm{ml})$ plus unmethylated GpC-ODN (30 $\mathrm{\mu g} / \mathrm{ml}$ ) and, at the indicated times, TNF $\alpha$ production $\left(\mathrm{pg} / \mathrm{ml} / 10^{6} \mathrm{cell} / \mathrm{s}\right)$ was monitored by ELISA (Euroclone, Celbio). Results are shown as means (SE). TNF $\alpha$ kinetic production was evaluated also with cell culture medium alone. 
patients with RA, using experimental conditions that tried to reproduce the physiological environment at the synovial level (similar percentage of T cells and monocytes). ${ }^{5}$

Five consecutive patients with RA entered the study. All patients gave their written informed consent. All patients had active-aggressive disease as defined by the high number of swollen joints (median 13, range 10-18) and by high $\mathrm{C}$ reactive protein values. The disease duration ranged between 2 and 14 years and their disease activity score ranged between 4.7 and 7.5, with a median value of 5.1. All the patients were analysed after a one month period of pharmacological wash out and four were still taking low doses of steroids.

Peripheral blood mononuclear cells were isolated by FicollPaque (Amersham Pharmacia Biotech) density gradient centrifugation and seeded at the $0.25 \times 10^{6} / \mathrm{ml}$ in 96 well plastic culture plates overnight at $37^{\circ} \mathrm{C} / 5 \% \mathrm{CO}_{2}$ in RPMI 1640 containing $10 \%$ fetal bovine serum (Euroclone, Celbio), 100 $\mathrm{U} / \mathrm{ml}$ of penicillin, and $100 \mu \mathrm{g} / \mathrm{ml}$ streptomycin. Non-adherent cells were removed by repeated washings with phosphate buffered saline. Flow cytometric analysis of the adherent cells using the Simultest (anti-leucocyte/CD45FITC and anti-LeuM3/CD14PE, Becton and Dickinson) gave the following results: monocytes 44.8 (SEM 2.1)\%, lymphocytes 38.2 ( 1.65$) \%$, granulocytes $12.9(3.8) \%$.

Cells were stimulated with $10 \mathrm{ng} / \mathrm{ml}$ LPS (from Salmonella typhimurium, L2262, Sigma) and/or $30 \mu \mathrm{g} / \mathrm{ml}$ CpG-ODN 2059 (5'-TCGTCGTTTTGTCGTTTTGTCGTT-3') or its negative control GpC-ODN 2077 (5'-GCTAGCTTTAGAGCTTTAGAGCTT-3') for $2,4,8$, and 24 hours following previously reported procedures. ${ }^{6}$ Tumour necrosis factor $\alpha$ (TNF $\left.\alpha\right)$ production was evaluated on the supernatants by ultrasensitive (range 0.5-32 $\mathrm{pg} / \mathrm{ml}$ ) enzyme linked immunosorbent assays (ELISAs; Biosource) when analysing ODN effect and by a less sensitive ELISA kit (Euroclone, Celbio) when analysing LPS alone or LPS plus the ODN effect. We reported the results as $\mathrm{pg} / \mathrm{ml}$ of TNF $\alpha$ per $10^{6}$ total mononuclear cells initially seeded. All assays were performed in triplicate and the mean value (SE) was taken.

Without stimulation (not treated) we found no significant TNF $\alpha$ production over the entire period of observation, indicating a lack of any significant adhesiveness induced activation on the cells. CpG-ODN as well as its negative control, GpC-ODN, produced only a slight perturbation in TNF $\alpha$ secretion, indicating a non-specific oligonucleotide linked effect (fig 1A). In contrast, we observed a reproducible intense response to LPS incubation, which was not significantly altered in the presence of CpG-ODN (fig 1B). Moreover, again no difference was seen between CpG and GpC-ODN effects, thus indicating that, in our experimental conditions, mononuclear cells do not show any evidence of a specific activation induced by bacterial-like DNA.

Recently, however, it has been shown that dendritic cells may increase CpG-ODN response in monocytes. ${ }^{7}$ Therefore it may well be that the presence of dendritic cells, in vivo as well as in vitro, is essential for bacterial DNA activation of mononuclear cells.

\section{Authors' affiliations}

B Tolusso, M Fabris, E Di Poi, R Assaloni, P Tomietto,

G F Ferraccioli, Division of Rheumatology, DPMSC, School of Medicine, University of Udine, Italy

B Tolusso and M Fabris contributed equally to this work.

Correspondence to: Professor G F Ferraccioli, Division of Rheumatology, DPMSC, School of Medicine, University of Udine, 33100 Udine, Italy;

gf.ferraccioli@med.uniud.it

Accepted 24 July 2002

\section{REFERENCES}

1 Shi F, Ljunggren H-G, Sarvetnik N. Innate immunity and autoimmunity:from self-protection to self-destruction. Trends Imunol $2001 ; 22: 97-101$

2 Zarember KA, Godowski PJ. Tissue expression of human Toll-like receptor and differential regulation of Toll-like receptor RNAs in leukocytes in response to microbes, their products and cytokines. J Immunol 2002;168:554-61.

3 Gao JJ, Hue Q, Papasian CJ, Morrison DC. Bacterial DNA and lipolysaccharide induce synergistic production of TNF- $\alpha$ through a post-transcription mechanism. J Immunol 2001;166:6855-60.

4 Ferraccioli GF, Mecchia F, Di Poi E, Fabris M. Anticardiolipin antibodies in rheumatoid patients treated with etanercept or conventional combination therapy: direct and indirect evidence for a possible association with infections. Ann. Rheum Dis. 2002;61:358-61.

5 Smeets TJ, Dolhain RJEM, Breedveld FC, Tak PP. Analysis of the cellular infiltrates and expression of cytokines in synovial tissue from patients with rheumatoid arthritis and reactive arthritis. J Pathol 1998;186:75-81.

6 Hartmann G, Krieg AM. CpG DNA and LPS induce distinct patterns of activation in human monocytes. Gene Ther, 1999;6:893-903.

7 Kaisho T, Akira S. Dendritic cell function in toll-like receptor and Myd88-knock-out mice. Trends Immunol 2001;22:78-83. 